\title{
GEOHYDROLOGY AND SIMULATION \\ OF GROUND-WATER FLOW IN THE \\ AQUIFER SYSTEM NEAR \\ CALVERT CITY, KENTUCKY
}

By J. Jeffrey Starn, Leslie D. Arihood, and Martin F. Rose

U.S. GEOLOGICAL SURVEY

Water-Resources Investigations Report 94-4239

Prepared in cooperation with the

KENTUCKY NATURAL RESOURCES AND

ENVIRONMENTAL PROTECTION CABINET

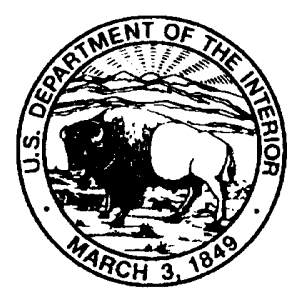

Louisville, Kentucky 


\title{
U.S. DEPARTMENT OF THE INTERIOR \\ BRUCE BABBITT, Secretary
}

\author{
U.S. GEOLOGICAL SURVEY \\ Gordon P. Eaton, Director
}

For additional information write to:

District Chief

U.S. Geological Survey

District Office

2301 Bradley Avenue

Louisville, KY 40217
Copies of this report can be purchased from:

U.S. Geological Survey

Earth Science Information Center

Open-File Reports Section

Box 25286, MS 517

Denver Federal Center

Denver, CO 80225 


\section{CONTENTS}

Abstract
Introduction
Purpose and scope of study
Methods of investigation
Acknowledgments
Recharge
Hydraulic properties of the aquifer system
Interaction of ground water and Cypress Creek

\section{PLATE (In Pocket)}

1. Diagram showing geologic sections of the Calvert City area, Kentucky

\section{FIGURES}

1. Map showing geographic features of the Calvert City area, Kentucky .................................................. 3

2. Diagram showing stratigraphy of the Calvert City area, Kentucky ..................................................5

3-4. Maps showing:

3. Generalized geology of the Calvert City area, Kentucky .......................................................... 6

4. Geologic features of the bedrock surface, Calvert City, Kentucky................................................. 7

5. Schematic of north-south section through the aquifer near Calvert City, Kentucky ............................ 10

6-7. Maps showing:

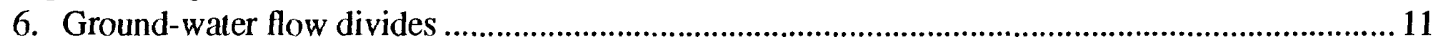

7. Location of ground-water withdrawals greater than 10,000 gallons per day in 1992 , and

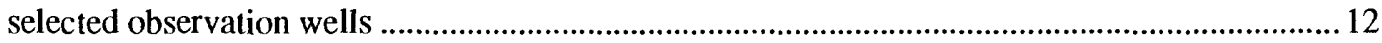

8. Graph showing average daily ground-water withdrawals in 1992, near Calvert City, Kentucky........... 13 
9-10. Maps showing:

9. Potentiometric surface, March 1992

10. Potentiometric surface, June 1992

11-14. Graphs showing:

11. Depth to water in the McNairy Formation at well UCC4 and rainfall, Calvert City, Kentucky ..... 17

12. Depth to water in the alluvium at well UCC3 and rainfall, Calvert City, Kentucky ....................... 18

13. Selected water levels affected by ground-water withdrawal, Calvert City, Kentucky .................... 19

14. Selected water levels affected by river stage, Calvert City, Kentucky .............................................2 20

15. Generalized geologic section at the Calvert City Municipal Water Supply Company,

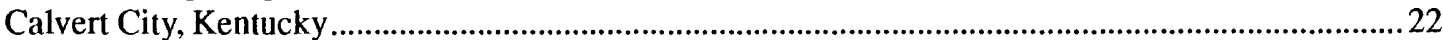

16-19. Maps showing:

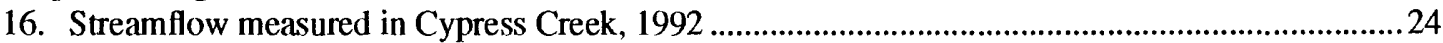

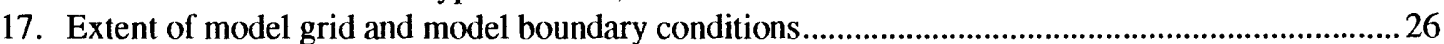

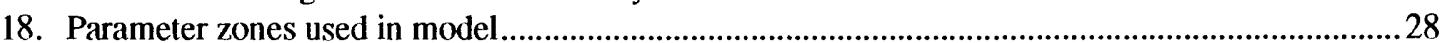

19. Potentiometric surface calculated with the calibrated model .....................................................33

20. Histogram of weighted differences between calculated and observed heads, Calvert City,

Kentucky

21-25. Maps showing:

21. Spatial distribution of weighted residuals

22. Contributing areas of discharge boundaries computed with the calibrated model, 1992 conditions

23. Contributing areas of discharge boundaries computed with the calibrated model, 1994 conditions

24. Time of travel computed with the calibrated model, 1994 conditions.

25. Location of nodes for which average linear velocity is calculated, 1994 conditions

TABLES

1. Model parameters estimated using nonlinear regression, Calvert City, Kentucky 31

2. Optimal parameter values obtained from nonlinear regression, Calvert City, Kentucky .......................31

3. Parameter values for alternative models computed by nonlinear regression, Calvert City, Kentucky .37

4. Water budget computed by alternative models, Calvert City, Kentucky ... 37

5. Pseudo-coefficients of variation for alternative models computed by nonlinear regression, Calvert City, Kentucky

6. Correlation and covariance matrix for optimum values obtained through nonlinear regression (CAL 1), Calvert City, Kentucky 39

7. Magnitude and direction of the average linear velocity at selected model cells under 1994 conditions, Calvert City, Kentucky 


\section{CONVERSION FACTORS AND VERTICAL DATUM}

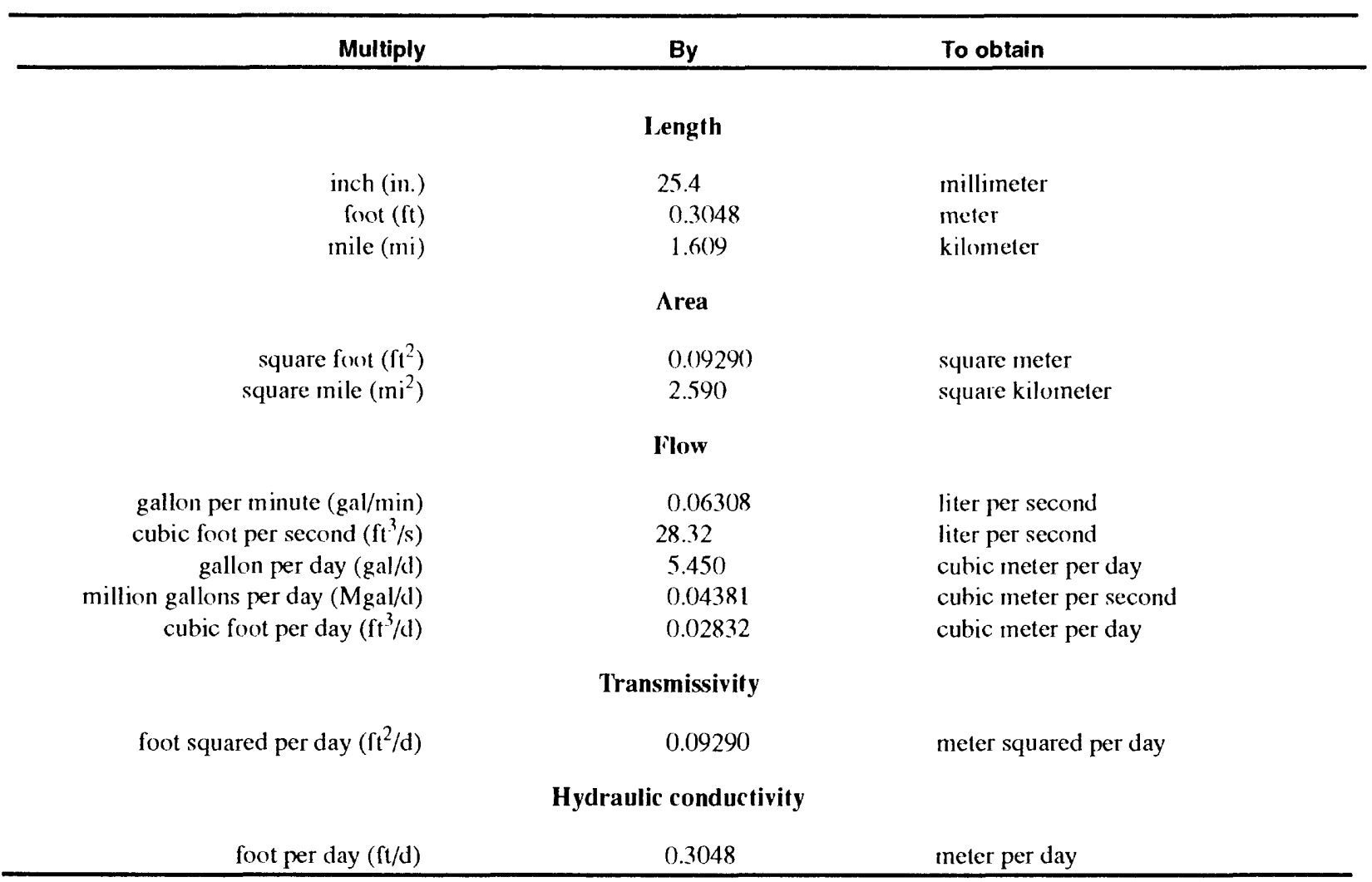

Sea level: In this report, "sea level" refers to the National Geodetic Vertical Datum of 1929 (NGVD of 1929)--geodetic datum derived from a general adjustment of the first-order level nets of both the United States and Canada, formerly called Sea Level Datum of 1929. 


\title{
Geohydrology and Simulation of Ground-Water Flow in the Aquifer System near Calvert City, Kentucky
}

\author{
By J. Jeffrey Starn, Leslie D. Arihood, and Martin F. Rose
}

\section{Abstract}

The U.S. Geological Survey, in cooperation with the Kentucky Natural Resources and Environmental Protection Cabinet, constructed a two-dimensional, steady-state ground-waterflow model to estimate hydraulic properties, contributing areas to discharge boundaries, and the average linear velocity at selected locations in an aquifer system near Calvert City, Ky. Nonlinear regression was used to estimate values of model parameters and their reliability. The regression minimizes the weighted difference between observed and calculated hydraulic heads and rates of flow. The calibrated model generally was better than alternative models considered, and although adding transmissive faults in the bedrock produced a slightly better model, fault transmissivity was not estimated reliably. The average transmissivity of the aquifer was 20,000 feet squared per day. Estimated recharge to two outcrop areas, the Cretaceous McNairy Formation and the Quaternary alluvium, was 0.00269 feet per day (11.8 inches per year) and 0.000484 feet per day (2.1 inches per year), respectively. Contributing areas to wells at the Calvert City Water Company in 1992 did not include the Calvert City Industrial Complex. Since completing the fieldwork for this study in 1992, the Calvert City Water Company discontinued use of its wells and began withdrawing water from new wells that were located 4.5 miles east-southeast of the previous location; the contributing area for these new wells moved farther from the industrial complex. The extent of the alluvium contributing water to wells was limited by the overlying lacustrine deposits. The average linear ground-water velocity at the industrial complex ranged from 0.90 to 4.47 feet per day with a mean of 1.98 feet per day.

\section{INTRODUCTION}

The Department for Environmental Protection (DEP) of the Kentucky Natural Resources and Environmental Protection Cabinet has made a comprehensive study of the Calvert City Industrial Complex to characterize the environmental conditions of the air, land, and water resources. The study consists of 21 major components, including ground-water modeling. The DEP study was designed to (1) incorporate area-wide and multi-media (air, soil, and water) information to assess the risk to public health and the environment caused by past waste disposal practices, (2) assist in the remediation and (or) abatement of risk, (3) plan for future protection of the resources of the area, and (4) facilitate the cooperation of the public, industry, and government in the management of risk in the area. The U.S. Geological Survey (USGS), in cooperation with the DEP, began an investigation of the ground-water component of the overall study. 


\section{Purpose and Scope}

This report describes briefly the geohydrology of the aquifer system at Calvert City, Ky., and presents results of a regional-scale simulation of ground-water flow. The hydrologic significance of geologic units in the study area are discussed using results of previous reports, measurements of streamflow, and observations of water levels. The effect of hydrologic factors on the ground-water-flow system were represented in a two-dimensional, steady-state, finite-difference ground-water-flow model. A nonlinear regression technique was used to calibrate the model. Estimates of the model parameters and their reliability are discussed. Contributing areas to discharge boundaries are displayed on maps. The magnitude and direction of the average linear velocity is tabulated for selected nodes in the model. Scenarios were evaluated with regard to changes in the ground-water flow system by simulating hypothetical locations and rates of withdrawal.

\section{Area of Study}

Calvert City, Ky., is in Marshall County in western Kentucky. The topography is characterized by flat areas and low, gently rolling hills. The area is bounded by Kentucky Lake on the east and the Tennessee River on the north. The main area of interest is centered on Calvert City and the Calvert City Industrial Complex; however, the area of study encompasses a larger area in order to incorporate the natural hydrologic boundaries of the ground-water flow system (fig. 1). The population of Calvert City is 2,531 (1990 census); the remainder of the area is rural and more sparsely populated. The industrial complex lies on the broad, flat terrace south of the Tennessee River. Several industries within the complex produce chemicals, including polyvinyl chloride, metal coatings, and paint additives. Other industries include production of graphite and metal alloys. Two companies provide waste-handling services to the chemical manufacturers. The methods of waste disposal within the complex include landfarming, incineration, treatment lagoons, and recycling. Many former waste-treatment lagoons have been closed.

\section{Methods of Investigation}

Methods used to describe the geohydrology and to evaluate the ground-water flow system include installation of observation wells, measurement of streamflow and ground-water levels, and numerical simulation. Six piezometers were constructed near the Calvert City well field for geologic description and water-level observation. Two synoptic water-level surveys were done using domestic wells, monitoring wells constructed for regulatory purposes, and the newly constructed observation wells. Geologic sections were constructed to complete the conceptual model.

Two-dimensional, steady-state ground-water flow in the aquifer near Calvert City, Ky., was simulated by use of the finite-difference computer program called MODFLOW (McDonald and Harbaugh, 1988). The parameters of the model were estimated using a nonlinear-regression method developed by Cooley and Naff (1990) and modified for use with MODFLOW by Hill (1992). The combined ground-water-flow model and nonlinear regression method are the basis for the computer program MODFLOWP (the suffix $P$ indicates parameter estimation). Other published case studies using nonlinear regression include, for example, evaluation of an alluvial aquifer (Yager, 1993) and a fractured carbonate-rock aquifer (Yager, in press). Alternative models were evaluated using statistics computed by use of MODFLOWP. The alternative models simulated different but equally plausible sets of hydrologic factors. The particletracking technique called MODPATH (Pollack, 1989) was used to compute the zones of contributing areas and the average linear velocities of the ground water. 

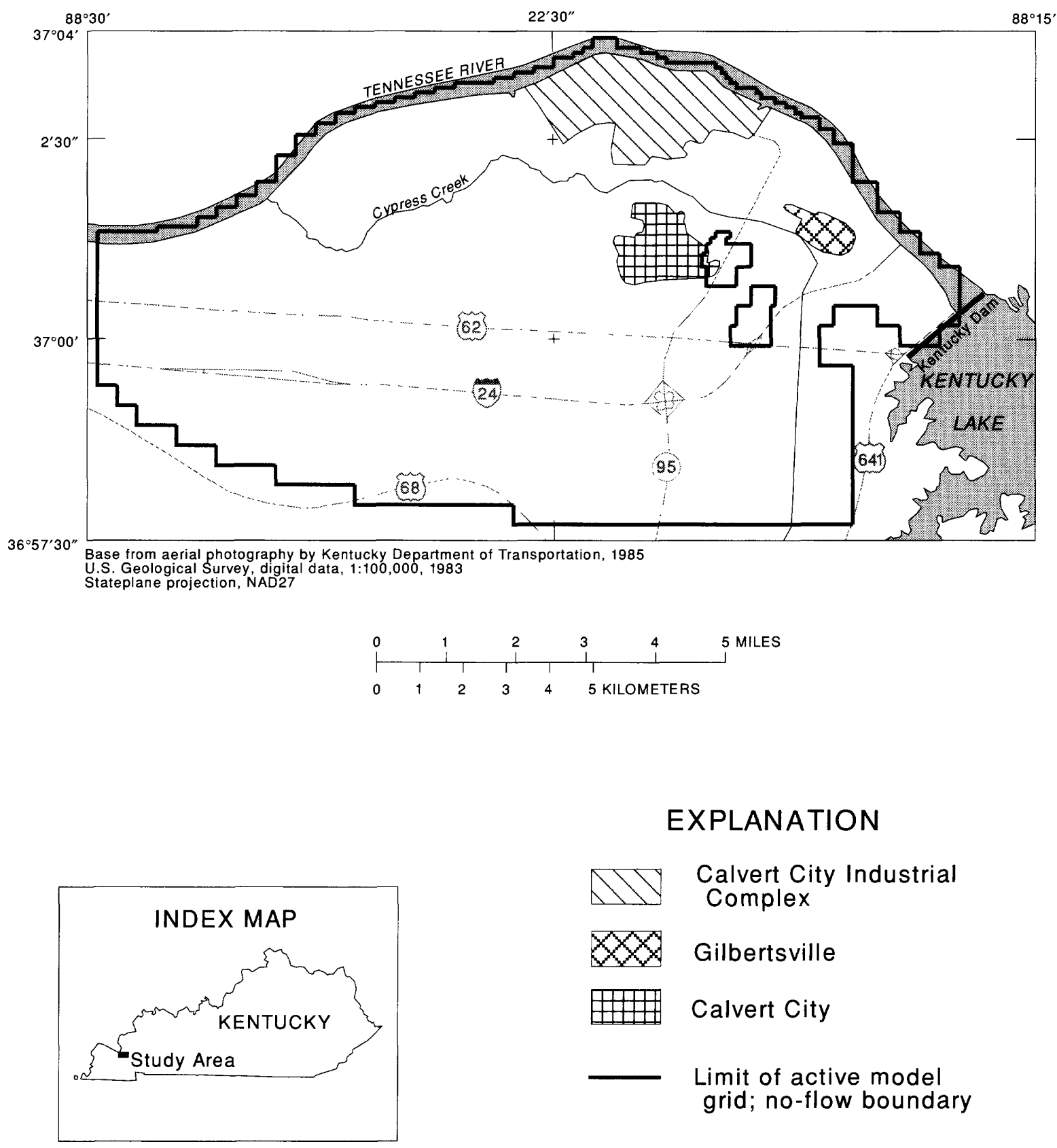

Figure 1. Geographic features of the Calvert City area, Kentucky. 


\section{Acknowledgments}

The authors acknowledge the contribution of industries within the Calvert City area that provided data for the project and to Calvert City for allowing the construction of observation wells on city property. Gay Brewer (B.F. Goodrich), Jerry Devine (Calvert City Water Company), Richard Nash (Calvert City), and Hans Conrad (Calvert City) were especially helpful.

\section{GEOHYDROLOGY}

The area lies within the Mississippi Embayment (Fenneman, 1938) physiographic region of western Kentucky. The Mississippi Embayment is a concave-upward, trough-shaped geologic structure consisting of, in part, Cretaceous and younger sediments. These sediments consist of partially consolidated and unconsolidated sand, clay, gravel, and silt. The sediments form a wedge that thickens from the edges of the embayment toward the Mississippi River. Ground water in the study area flows from the upland areas south of Calvert City and north toward the Tennessee River, whereas flow in other parts of the Mississippian Embayment is to the southwest toward the Mississippi River. Ground water in the study area discharges to the Tennessee River, to supply wells, and to the upper and lower reaches of Cypress Creek.

\section{Geology}

The lithology, structure, and stratigraphy of the study area were described by Olive (1980) and by the authors of the 7.5-minute geologic-quadrangle maps (Olive, 1963; Lambert and MacCary, 1964; Amos and Wolfe, 1966; Amos and Finch, 1968). The geologic units discussed in this report are Mississippian limestones; Cretaceous sand, clay, and gravel deposits; Tertiary gravel deposits; and Quaternary deposits of gravel, sand, silt, and clay (fig. 2).

Two bedrock units have hydrologic significance in the study area-the Fort Payne Formation and the Warsaw Limestone - both of which crop out along Kentucky Lake (fig. 3). The Fort Payne Formation contains limestone and chert in interbedded layers 0.1 to $2.0 \mathrm{ft}$ thick. It is dense, finely crystalline, and locally shaly. The limestone also crops out along the Tennessee River west of the industrial complex and in the bed of Cypress Creek $1 \mathrm{mi}$ west of Calvert City (Amos and Finch, 1968). Upon weathering, the Fort Payne Formation produces angular fragments of chert in a porous, fine-grained matrix. The Warsaw Limestone is a thick-bedded limestone composed of megascopic fossil fragments in a fine-grained limestone matrix. Some beds of fine-grained limestone are interspersed throughout the formation. The Warsaw Limestone rarely crops out and weathers to a silty clay texture that contains some porous zones of chert fragments. Either the Fort Payne Formation or the Warsaw Limestone underlies the unconsolidated deposits throughout the study area.

The buried surface of the bedrock (fig. 4) is characterized by the presence of a buried valley and by the degree of weathering and fracturing of the rock. The deepest part of the buried valley is located $1.5 \mathrm{mi}$ south of the present course of the Tennessee River. This valley is defined approximately by the $220 \mathrm{ft}$ topographic contours on figure 4. Although the bedrock units were deposited in a marine environment, they were subsequently exposed to weathering for a long period of time-perhaps 180 million years (Davis and others, 1973). Soil zones formed on the surface of the rocks, and deep leaching of carbonate minerals resulted in the formation of karst topography with its characteristic subsurface drainage. Where limestone lies beneath unconsolidated surficial sediments, it is fractured and weathered to a depth of 5 to $25 \mathrm{ft}$. Where the Warsaw Limestone overlies the Fort Payne Formation, such as beneath the Calvert City Industrial 


\begin{tabular}{|c|c|c|c|c|}
\hline$\underset{\substack{w \\
\infty}}{\stackrel{\infty}{\infty}}$ & 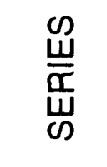 & FORMATION & $\begin{array}{l}\text { THICKNESS, } \\
\text { IN FEET }\end{array}$ & DESCRIPTION \\
\hline \multirow{4}{*}{ 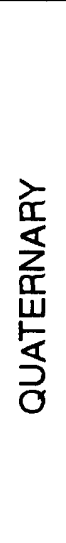 } & \multirow{4}{*}{ 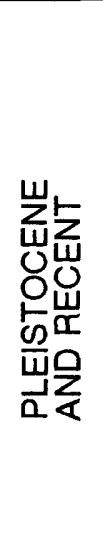 } & \multirow{3}{*}{ ALLUVIUM } & $8-10$ & $\begin{array}{l}\text { Upper unit: clayey silt and silty clay } \\
\text { of lacustrine origin }\end{array}$ \\
\hline & & & $30-50$ & $\begin{array}{l}\text { Middle unit: silty sand, clayey sand, } \\
\text { and clean sand; interbedded. }\end{array}$ \\
\hline & & & $50-70$ & $\begin{array}{l}\text { Lower unit: gravelly sand and sandy } \\
\text { gravel; well-sorted; may be reworked } \\
\text { and redeposited Continental Deposits. }\end{array}$ \\
\hline & & LOESS & $0-18$ & $\begin{array}{l}\text { Silt, variably clayey; grades into } \\
\text { lacustrine deposits }\end{array}$ \\
\hline 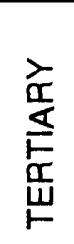 & 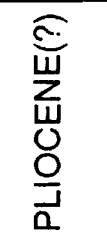 & $\begin{array}{l}\text { CONTINENTAL } \\
\text { DEPOSITS }\end{array}$ & $0-60$ & $\begin{array}{l}\text { Gravel; chert and quartz, well-rounded } \\
\text { to angular iron-stained pebbles and } \\
\text { cobbles. Sand; mostly quartz and chert } \\
\text { as matrix in gravel. Iron cemented and } \\
\text { clay beds in places. }\end{array}$ \\
\hline \multirow[t]{2}{*}{$\begin{array}{l}\frac{1}{山} \\
\frac{0}{0} \\
\frac{0}{D}\end{array}$} & \multirow[t]{2}{*}{ 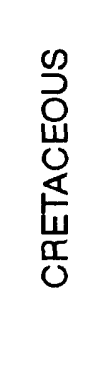 } & MCNAIRY & $0-200$ & $\begin{array}{l}\text { Sand, clay, and gravel; in part } \\
\text { interbedded; sand, loose, well-sorted, } \\
\text { medium-grained quartz sand; clay, thin } \\
\text { layers and irregular masses; gravel, } \\
\text { chert pebbles in matrix of medium- } \\
\text { grained quartz sand. }\end{array}$ \\
\hline & & TUSCALOOSA & $0-50$ & $\begin{array}{l}\text { Deeply weathered chert rubble; not } \\
\text { continuous. }\end{array}$ \\
\hline \multirow{2}{*}{$\begin{array}{l}z \\
\frac{\alpha}{0} \\
\frac{0}{0} \\
\frac{0}{0} \\
\frac{0}{\infty} \\
\frac{D}{\Sigma}\end{array}$} & 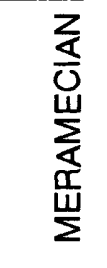 & $\begin{array}{l}\text { WARSAW } \\
\text { LIMESTONE }\end{array}$ & $550-720$ & $\begin{array}{l}\text { Limestone, thick bedded; coarse } \\
\text { fossil fragments in fine-grained } \\
\text { limestone matrix; interspersed beds of } \\
\text { fine-grained limestone. }\end{array}$ \\
\hline & 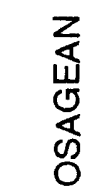 & FORT PAYNE & $500+-$ & $\begin{array}{l}\text { Limestone; dense and finely } \\
\text { crystalline; shale laminae and } \\
\text { interbedded chert. Shaly in lower part. }\end{array}$ \\
\hline
\end{tabular}

Figure 2. Stratigraphy of the Calvert City area, Kentucky. (Modified from Olive, 1963; Lambert and MacCary, 1964; Amos and Wolfe, 1966; and Amos and Finch, 1968.) 

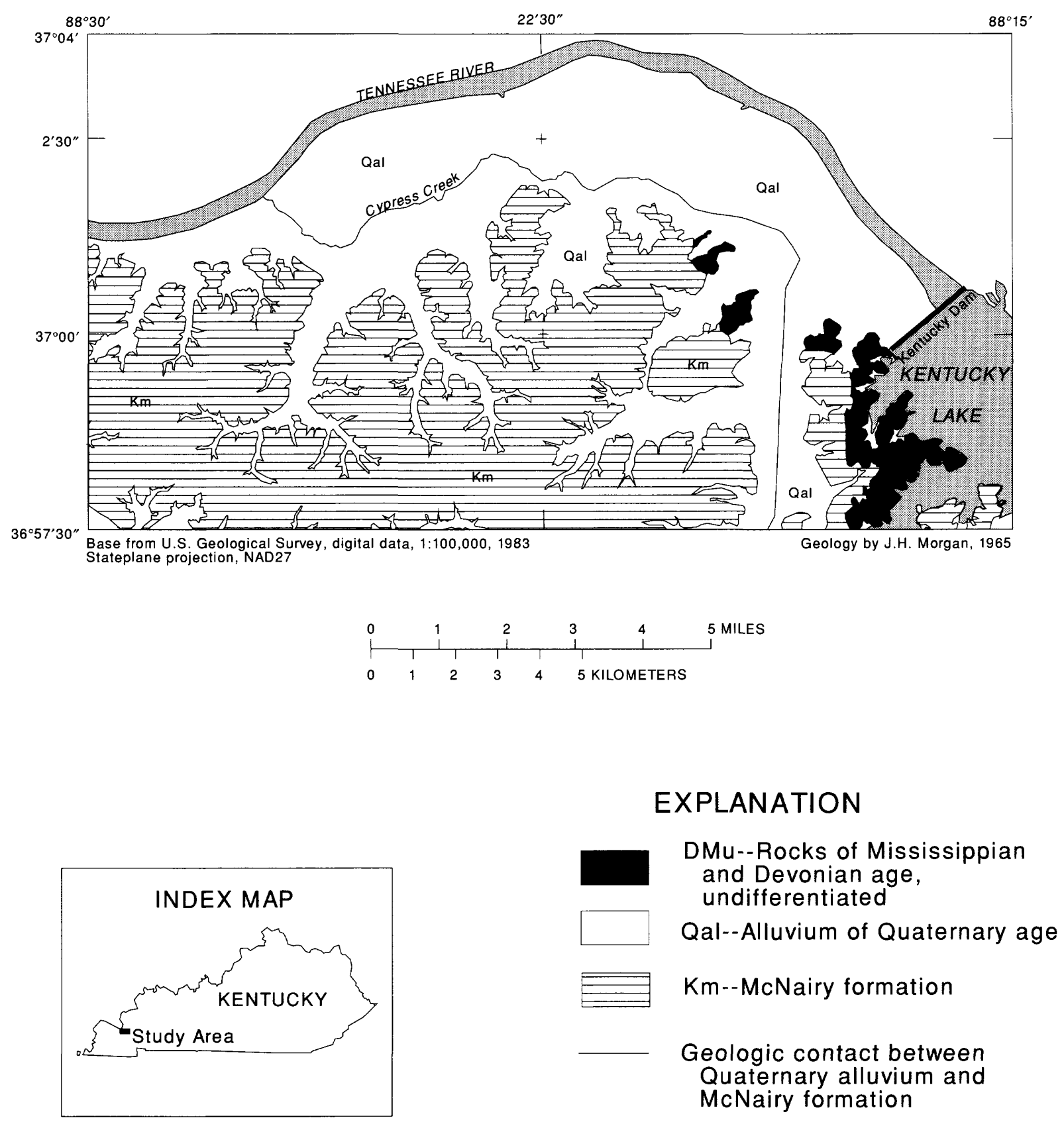

Figure 3. Generalized geology of the Calvert City area, Kentucky. 

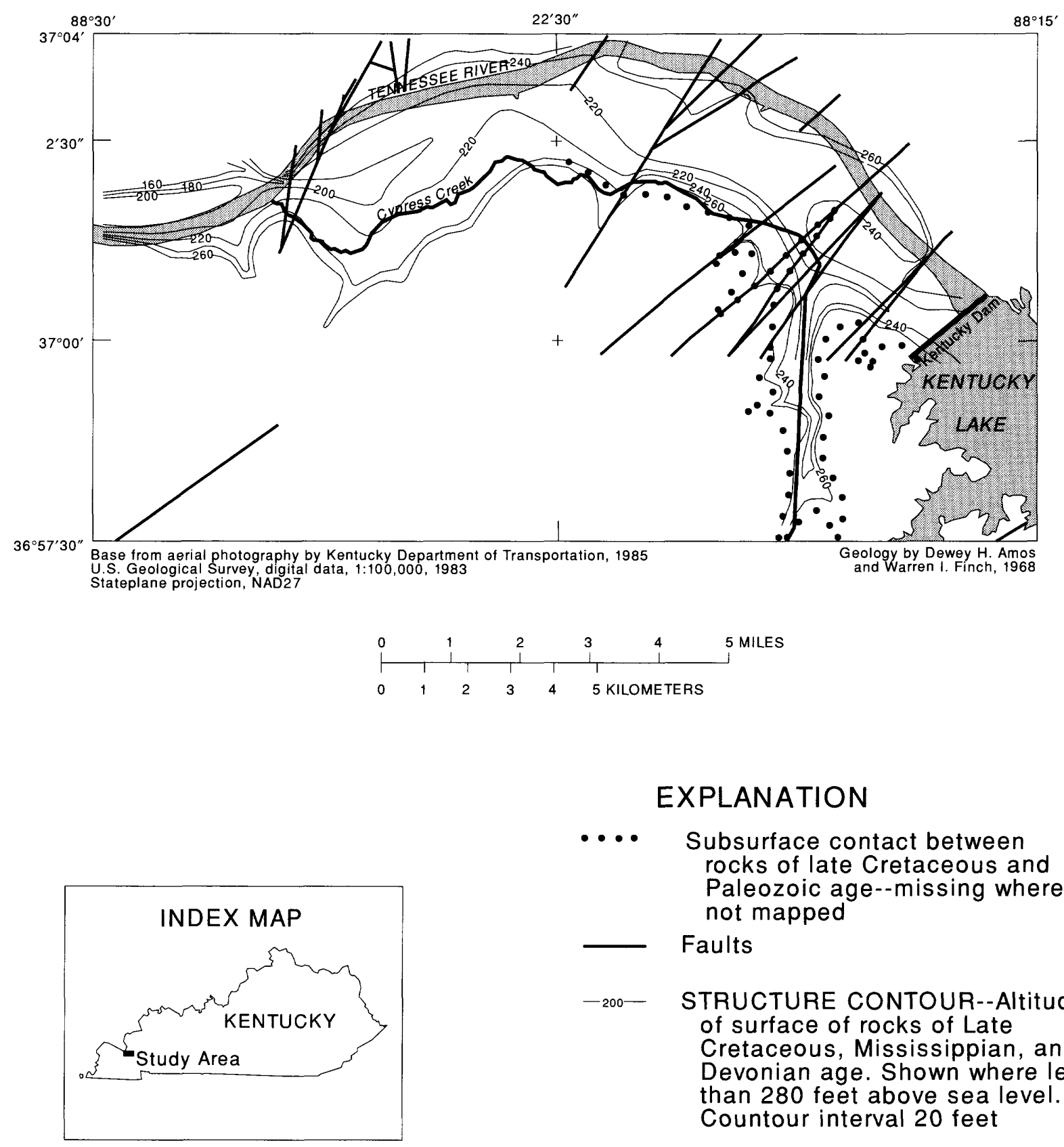

\section{EXPLANATION}

-.. Subsurface contact between rocks of late Cretaceous and Paleozoic age--missing where not mapped

Faults

-200- STRUCTURE CONTOUR--Altitude of surface of rocks of Late Cretaceous, Mississippian, and Devonian age. Shown where less than 280 feet above sea level. Countour interval 20 feet

Figure 4. Geologic features of the bedrock surface, Calvert City, Kentucky. 
Complex, the Fort Payne Formation is relatively free of fractures (Finch, 1968). The bedrock surface is marked hy northeast-trending near-vertical normal faults that displace Paleozoic and Cretaceous strata less than 100 ft vertically (Davis and others, 1973).

Cretaceous sediments overlie the limestone bedrock in the southem part of the study area (fig. 3 and pl. 1). The Tuscaloosa Formation is a deeply weathered and broken chert rubble that is present in discontinuous patches on the bedrock surface. The McNairy Formation overlies the Tuscaloosa Formation or the limestome bedrock and was deposited in a marine to freshwater deltaic environment during the Late Cretaceous Period at the northeastern end of the Mississippi Embayment. This formation is composed of interbedded sand, clay, and gravel. The sand is generally loose, well-sorted, medium-grained quartz sand, although, in places, it can he well-cemented by iron minerals. The clay is present in thin layers and irregular masses. The gravel is predominantly chert pebbles in a porous matrix of medium-grained quartz. sand. The fommation thickens from its outcrop near Kentucky Lake to $200 \mathrm{ft}$ in the southwestern part of the study area. The base of the McNairy Formation crops out near Kentucky Lake where it is a gravelly sand or sandy gravel.

Gravel and sand continental deposits of Pliocene or Pleistocene age overlie the McNairy Formation on some hilltops. These sediments were deposited by high-velocity hraided streams as channel deposits. The gravel generally is composed of fairly well-consolidated chert and sandstone blocks in a matrix of poorly sorted coarse sand. A Pleistocene loess deposit overlies the McNairy Formation and the continental deposits on hilltops. The loess is a wind-blown deposit composed of silt with variable amounts of clay and sand intermixed.

Alluvial deposits are subdivided into upper, middle, and lower units (Finch, 1968) that reflect different depositional environments (pl. 1). The lower unit formed during Pliocene or Pleistocene time as continental deposits on surrounding hilltops eroded and coarse material was transported into the incised bedrock valley. The unit consists of 50 to $70 \mathrm{ft}$ of well-sorted gravelly sand and sandy gravel (Finch, 1968). In valleys occupied by small rivers and creeks, the lower gravel is thin, absent, or clayey (Davis and others, 1973). Although this unit overlies limestone in most places, it overlaps the McNairy Formation in the area near their surficial contact. The middle unit was formed as the Ohio River aggraded its valley during the Pleistocene Epoch. It is a transition sequence of interbedded sand, silt, and clay that represents channel sands, point bar accumulations, and overbank deposits on top of the valley-fill sand and gravel. The middle unit consists of 30 to $50 \mathrm{ft}$ of noncohesive silty sand, clayey sand, and clean sand. In a splitspoon sample collected at the Calvert City Water Company, the middle unit consists of alternating layers of sand and clay about 2 in. thick. The upper unit is a massive deposit of lake-bed silt and clay that accumulated when the river was blocked with sediment during Pleistocene time. These lacustrine deposits form the uppermost geologic unit over most of the Tennessee River floodplain and consist of 8 to $10 \mathrm{ft}$ of cohesive unconsolidated clayey silt and silty clay.

In the north-central part of the study area adjacent to the Tennessee River, some well logs slow a distinct, continuous bluish-gray to maroon clay layer from a depth of $40 \mathrm{ft}$ below land surface to the bottom of the borehole at a depth of $80 \mathrm{ft}$. This clay forms a low-permeability zone along the Tennessee River. The extent of the clay is unknown.

\section{Hydrology}

The dominant hydrologic features of the study area are the Tennessee River and Kentucky Lake. The mean annual discharge of the Tennessee River for 1992 was $50,301 \mathrm{ft}^{3} / \mathrm{s}$. In June 1992 , when many of the data used in this report were collected, the minimum, mean, and maximum discharges were $16,658 \mathrm{ft}^{3} / \mathrm{s}$, $38,282 \mathrm{ft}^{3} / \mathrm{s}$, and $82,664 \mathrm{ft}^{3} / \mathrm{s}$, respectively (Morgan Goranflo, Tennessee Valley Authority, written 
commun., 1994). Normal pool stage in the Tennessee river is $302 \mathrm{ft}$; flow in the Tennessee River is controlled by the Kentucky Dam, which impounds Kentucky Lake. The normal pool stage in Kentucky Lake is $359 \mathrm{ft}$. Major tributaries to the Tennessee River near Calvert City are Cypress Creek and East Fork Clarks River. The Tennessee River flows into the Ohio River at Paducah, Ky. about 20 river miles downstream from the study area.

The aquifer system underlying the study area comprises two aquifers: one aquifer in the lower unit of the alluvium and one aquifer in sands of the McNairy Formation (fig. 5). The upper 5 to $25 \mathrm{ft}$ of the limestone bedrock was weathered to a granular texture similar to the overlying sediments and were included with the overlying aquifers. The aquifer system is bounded by ground-water flow divides, Kentucky Lake, and the Tennessee River (fig. 6) based on the regional potentiometric surface (Davis and others, 1973), topography, and geology (MacCary, 1964; Morgan, 1964). The southwestern boundary of the aquifer system is a ground-water flow divide that separates discharge to East Fork Clarks River and the Tennessee River. The eastern boundary of the aquifer system is the outcrop of consolidated rocks between the aquifer and Kentucky Lake. The southem boundary is a topographic high where the aquifer is overlain by a confining layer (the zone of "perched water" described by MacCary (1964) and Morgan (1964)). The confining layer results in a high plateau on the potentiometric surface from which ground water flows southeast to the headwaters of Cypress Creek and north into the aquifer system underlying the study area.

\section{Ground Water}

\section{Withdrawals and Availability}

Approximately 23 percent of the water used for municipal and industrial water supply in Marshall County is ground water (Sholar and Lee, 1988). Permits are required from the Kentucky Division of Water for ground-water withdrawals greater than $10,000 \mathrm{gal} / \mathrm{d}$; the following two companies in the area (companies A and B in this report), and the Calvert City Water Company, have such permits (figs. 7 and 8). Since completing the fieldwork for this study in 1992, the Calvert City Water Company discontinued use of their wells and hegan withdrawing water from new wells located $4.5 \mathrm{mi}$ east-southeast of the previous location (Jerry Devine, Calvert City Water Company, oral commun., 1994). Also, another company (company C) operated 32 wells in June 1992 to remove contaminated ground water from the aquifer. The combined rate of pumping from these wells was approximately $650 \mathrm{gal} / \mathrm{min}$ during the start-up phase of the remediation in June 1992.

Well yields in the area generally are high but depend on local geologic conditions. Yields from the lower alluvial unit can be high; one well reportedly yielded a sustained rate of 1,200 gal/min during an aquifer test (Davis and others, 1973). Other wells in the lower alluvial unit yield as much as $650 \mathrm{gal} / \mathrm{min}$. The McNairy Formation yields sufficient water for domestic use (Pree and Walker, 1952), but the maximum potential to yield water has not been explored. Where the top of the Fort Payne Formation is overlain by sediments of Cretaceous age and younger, it is weathered and fractured into a chert rubble that can yield large amounts of ground water to wells (Davis and others, 1973). In general, yields from the weathered limestone can exceed $125 \mathrm{gal} / \mathrm{min}$ (Pree and Walker, 1952). Localized transmissive faults in the limestone also can supply large quantities of water to wells. The spacing of faults that produce large quantities of water, however, is not known. 


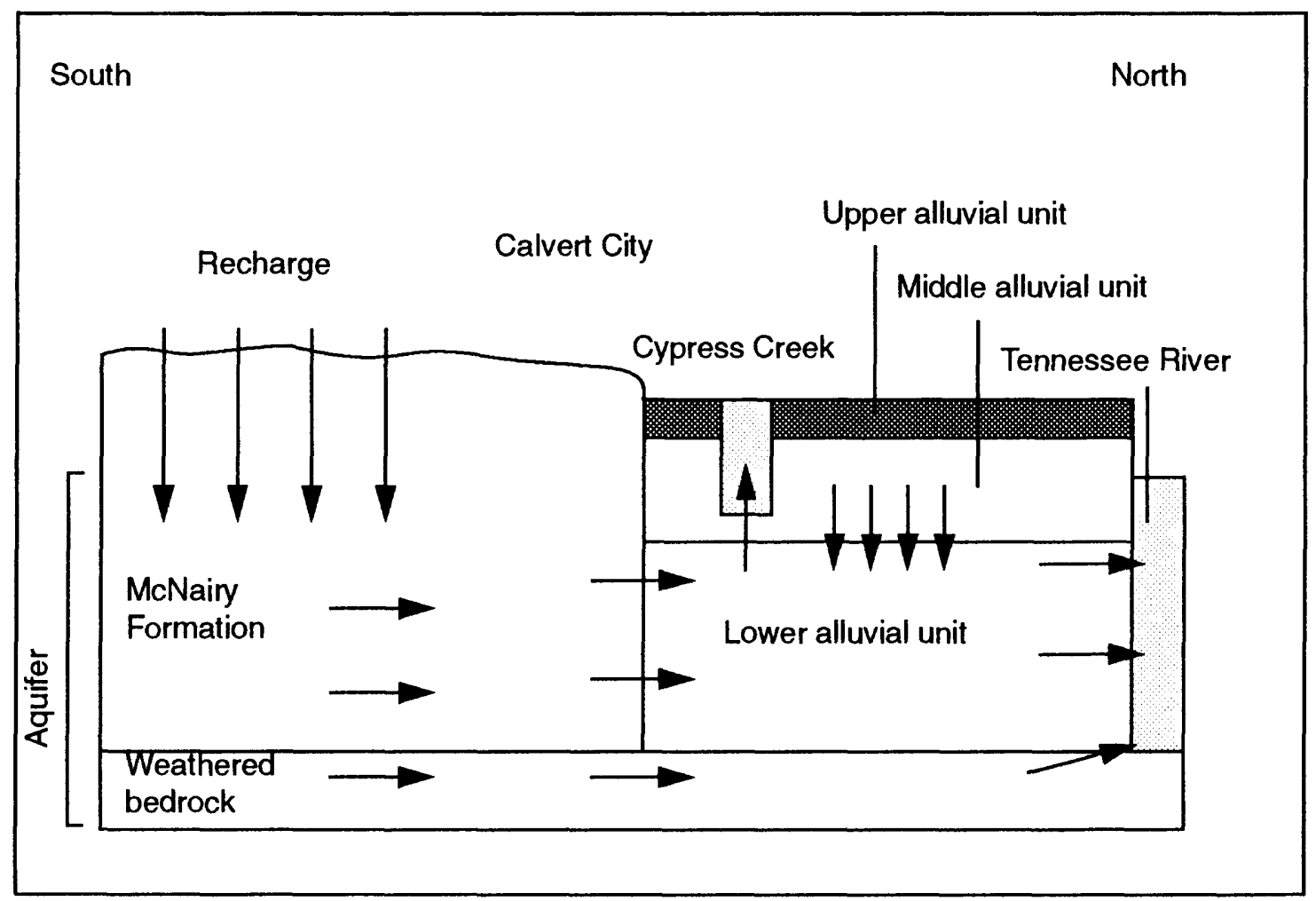

NOT TO SCALE

\section{EXPLANATION}

Direction of ground-water flow

Figure 5. North-south section through the aquifer near Calvert City, Kentucky. 


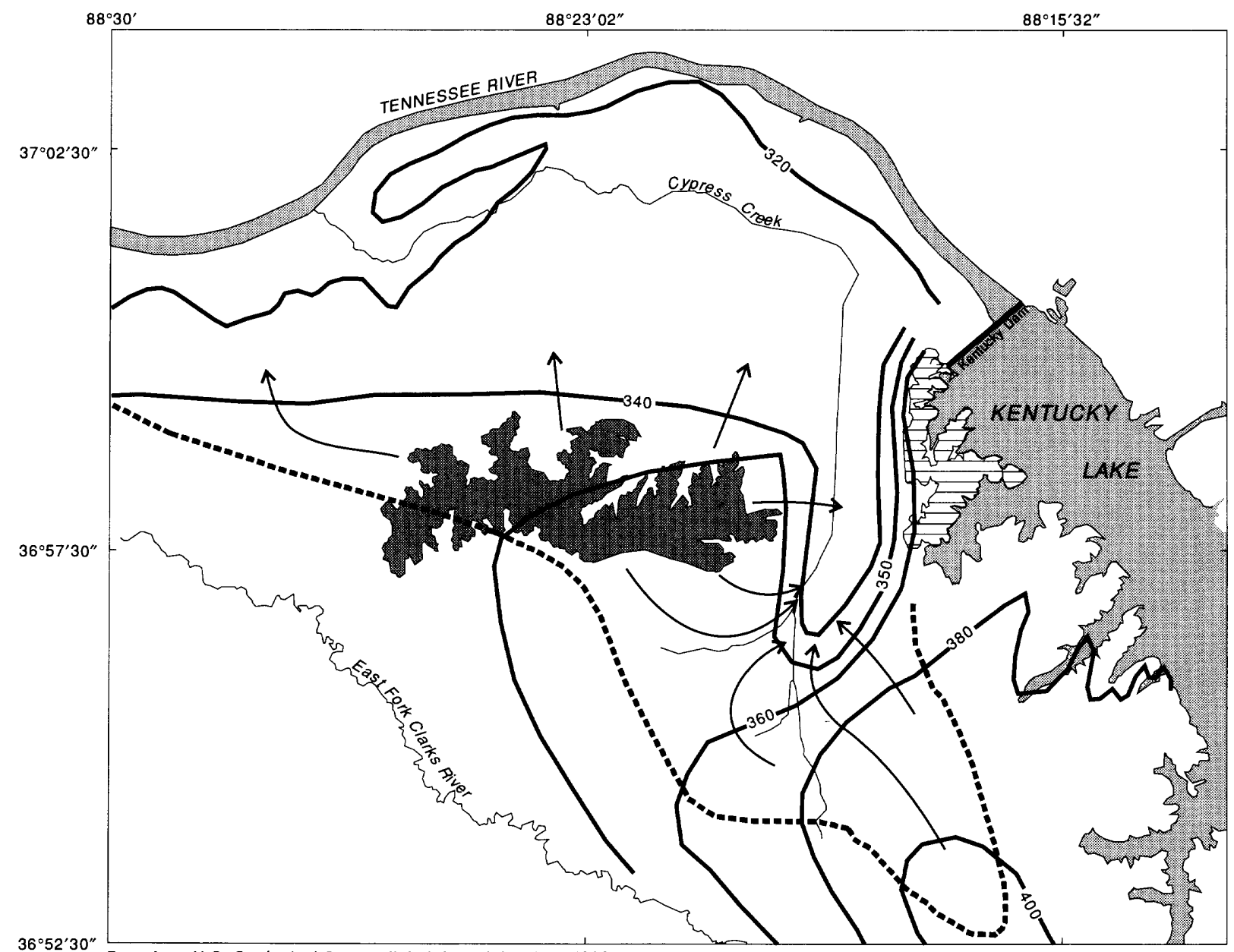

Base from U.S. Geological Survey digital data, 1:100,000, 1983 Stateplane Projection NAD27

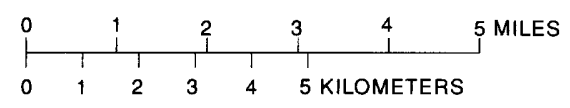

\section{EXPLANATION}

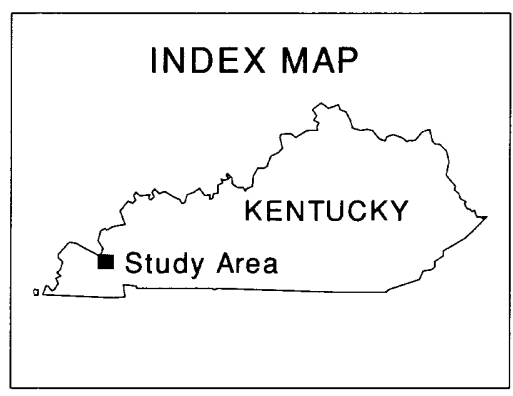

$\mathrm{Km}$--Area of perched aquifer (from Morgan, 1964; and MacCary, 1964)

Bedrock outcrop

\section{Ground-water divide}

- 320- Water-level contour--contour intervals 10 and 20 feet. Datum is sea level. (From Davis and others, 1973; plate 10.)

Generalized direction of ground-water flow

Figure 6. Ground-water flow divides. 

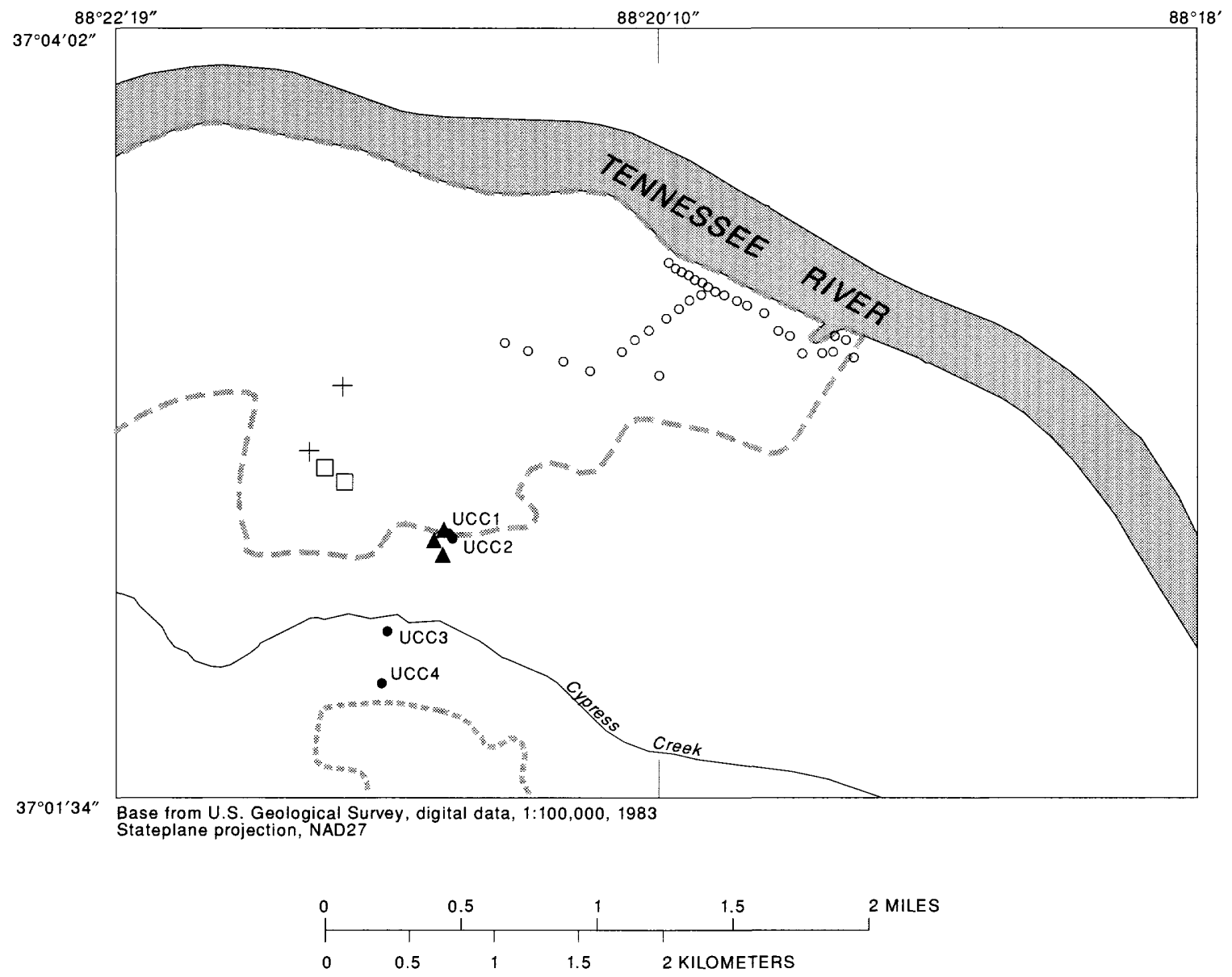

\section{EXPLANATION}

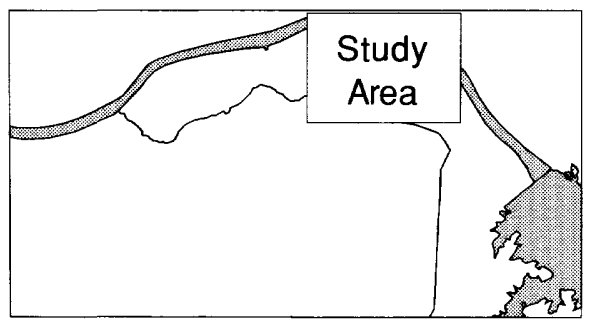

+ Wells at company $A$

$\square \quad$ Wells at company $B$

- Wells at company $C$

- Calvert City Water Company wells

ucC1 USGS observation wells and identifier

Calvert City

$[-1$ Calvert City industrial complex

Figure 7. Location of ground-water withdrawals greater than 10,000 gallons per day in 1992 and selected observation wells. 


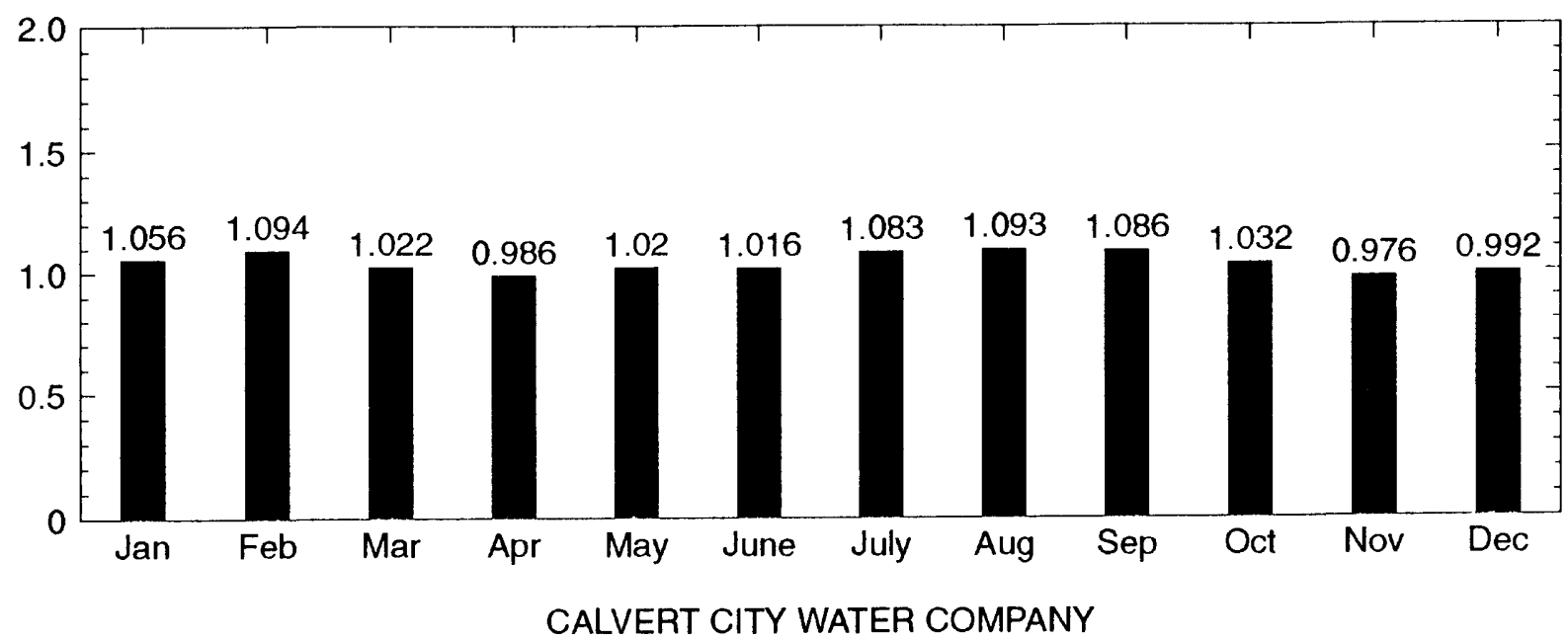

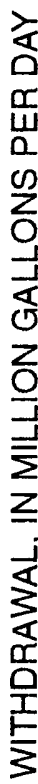

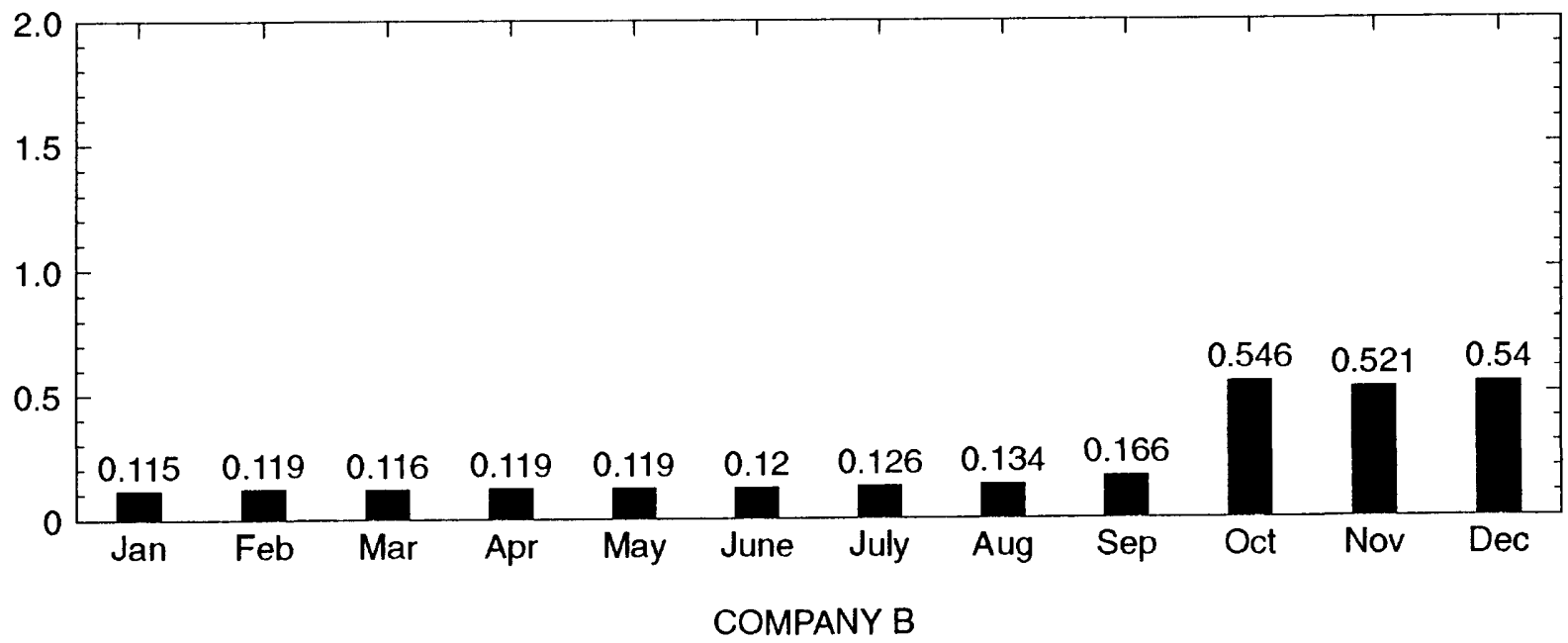

Figure 8. Average daily ground-water withdrawals in 1992, near Calvert City, Kentucky. 
The type and location of domestic wells varies with geology, local well-drilling practices, and availability of publicly supplied water. Most of the residences over the alluvial deposits west of Calvert City depend on ground water. The wells generally are open-ended, 24-in. diameter wells cascd with concrete in 2-ft sections and are less than $50 \mathrm{ft}$ deep. In contrast, most residences south of Calvert City use small-diameter drilled wells ranging from $50 \mathrm{ft}$ deep to more than $100 \mathrm{ft}$ deep. The areas around Calvert City, southwest of Calvert City, and Gilbertsville are served by publicly supplied water; however, some residences have wells for occasional use. Two golf courses and a State-owned tree farm in the area use ground water for irrigation at a rate less than $10,000 \mathrm{gal} / \mathrm{d}$.

\section{Levels}

Water levels were measured in monitoring wells at eight industrial plants and in privately owned domestic water-supply wells twice in 1992. The first set of 157 measurements was made from March 17 to 20. A subset of 119 wells was visited again from June 23 to 25 . These data were used to produce contour maps of the potentiometric surfaces (figs. 9 and 10). The shapes of the $320 \mathrm{ft}$ and $330 \mathrm{ft}$ potentiometric contours were similar to the geologic contact between the McNairy Formation and the alluvium (fig. 3), indicating that the aquifers on each side of the contact are hydrologically different. The potentiometricsurface maps show that the contours are generally in the same positions as noted hy Davis and others (1973) (fig. 6); therefore, on the basis of these limited data, there does not seem to be a long-term trend in water levels. The long open loop at the western end of the 320-ft contour on figure 5 was drawn by Davis and others (1973) on the basis of a single water-level measurement. The 320-ft contours in figures 9 and 10 differ from figure 5, although not significantly in terms of the general position of the contour.

Water levels in each aquifer in the aquifer system responded slightly different to natural recharge. Water levels in the McNairy Formation and the alluvium responded to both daily and seasonal fluctuations in recharge (figs. 11 and 12). Water levels in the McNairy Formation fluctuate more to individual rainfall events and to seasonal recharge (fig. 11) than water levels in the alluvium. Water levels in bedrock wells along the shore of Kentucky Lake coincide with those in the overlying McNairy Formation because the two are hydraulically connected in this area (Davis and others, 1973).

Water levels in the aquifer system also may fluctuate because of changes in barometric pressure, ground-water withdrawals, and river stage caused by releases of water from Kentucky Dam. The water level in wells was reported by Davis and others (1973) to vary by as much as $1 \mathrm{ft}$ over a 2-3 day period in response to fluctuations in air pressure; however, water levels in March and June 1992 varied by less than $0.1 \mathrm{ft}$ in one well that was measured several times during each synoptic measurement period. Water levels in the alluvium also respond to ground-water withdrawal at the Calvert City Water Company (fig. 13). Water levels in the middle and lower units of the alluvium respond to changes in stage in the Tennessee River (Dames and Moore, 1988a) (fig. 14). The duration of the high water levels in wells was approximately equal to the duration of the rise in river stage. The change in stage was propagated rapidly through the aquifer and was observed at the most distant observation well, 2,000 ft from the river. 

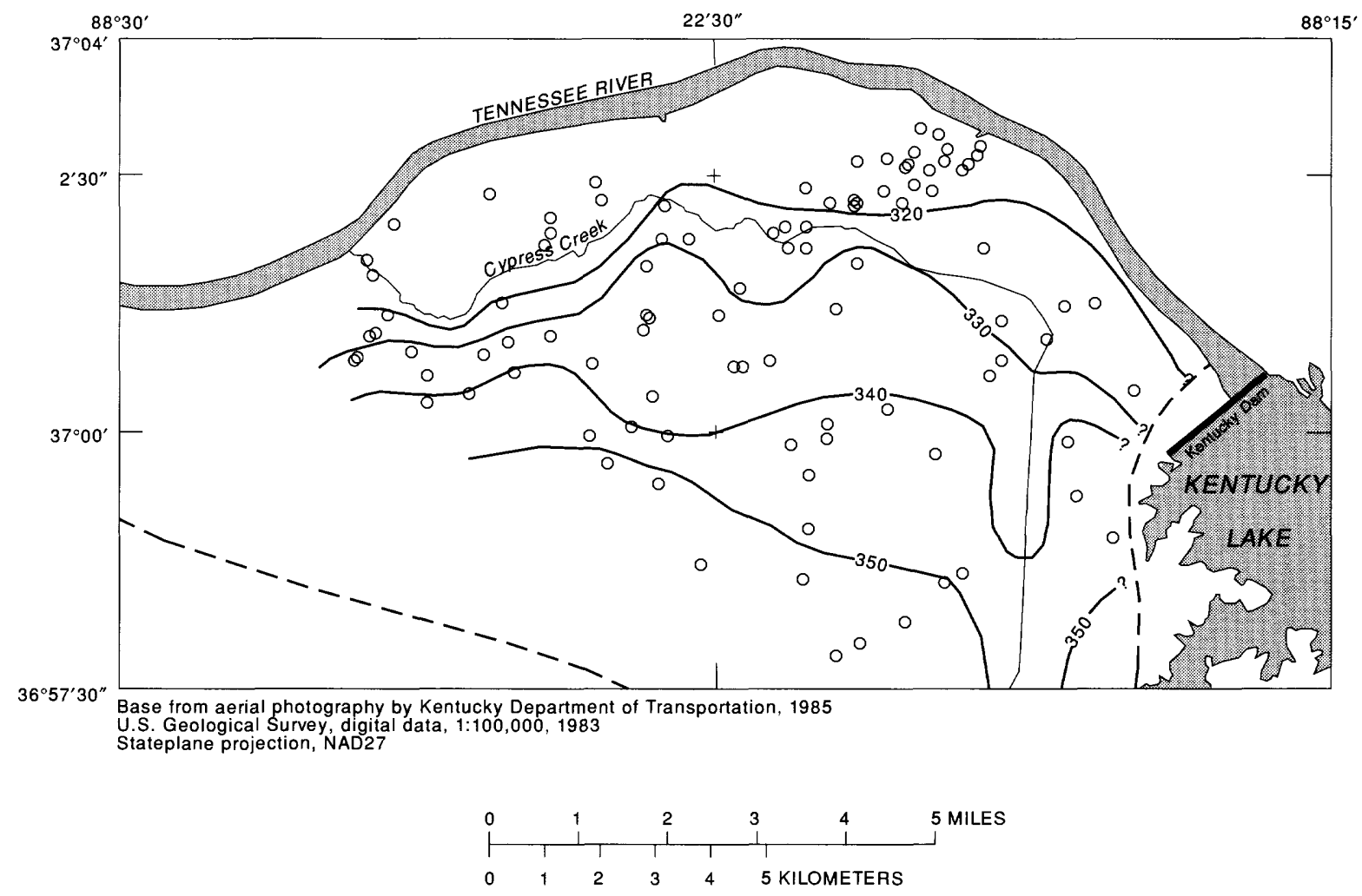

\section{EXPLANATION}

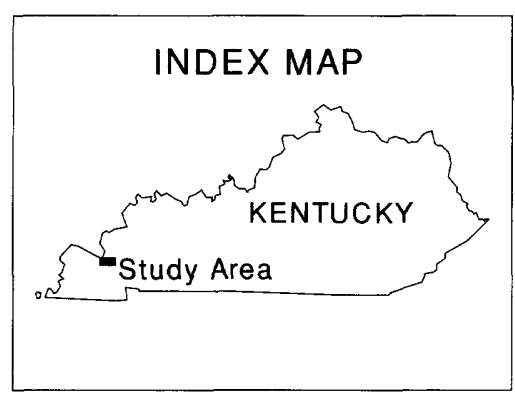
- 300 - POTENTIOMETRIC CONTOUR-- Shows altitude at which water would have stood in tightly cased wells, March 1992. Contour interval 10 feet. Datum is sea level.
- - Ground-water divide
- Data points for potentiometric contours

Figure 9. Potentiometric surface, March 1992. 

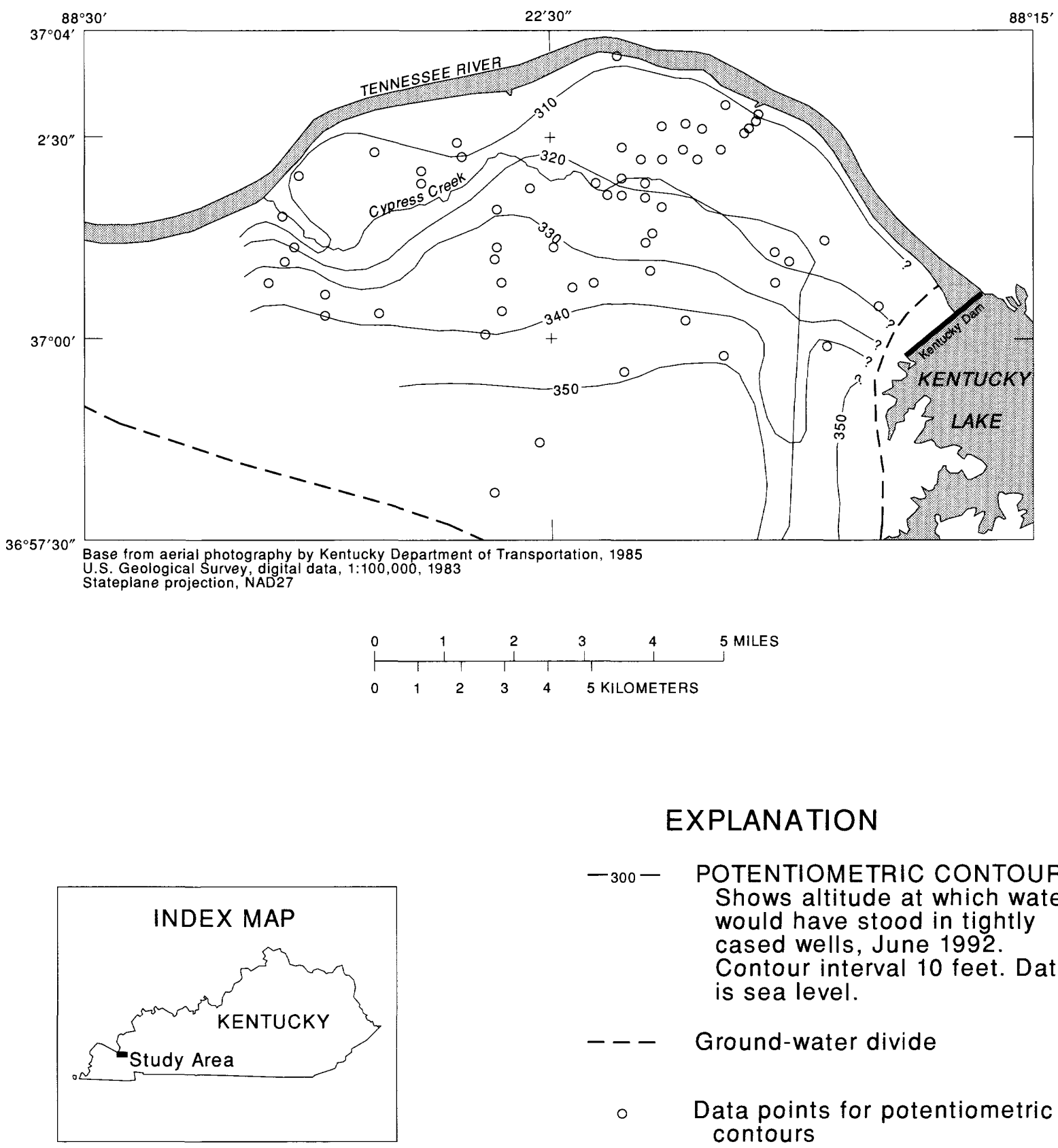

Figure 10. Potentiometric surface, June 1992. 


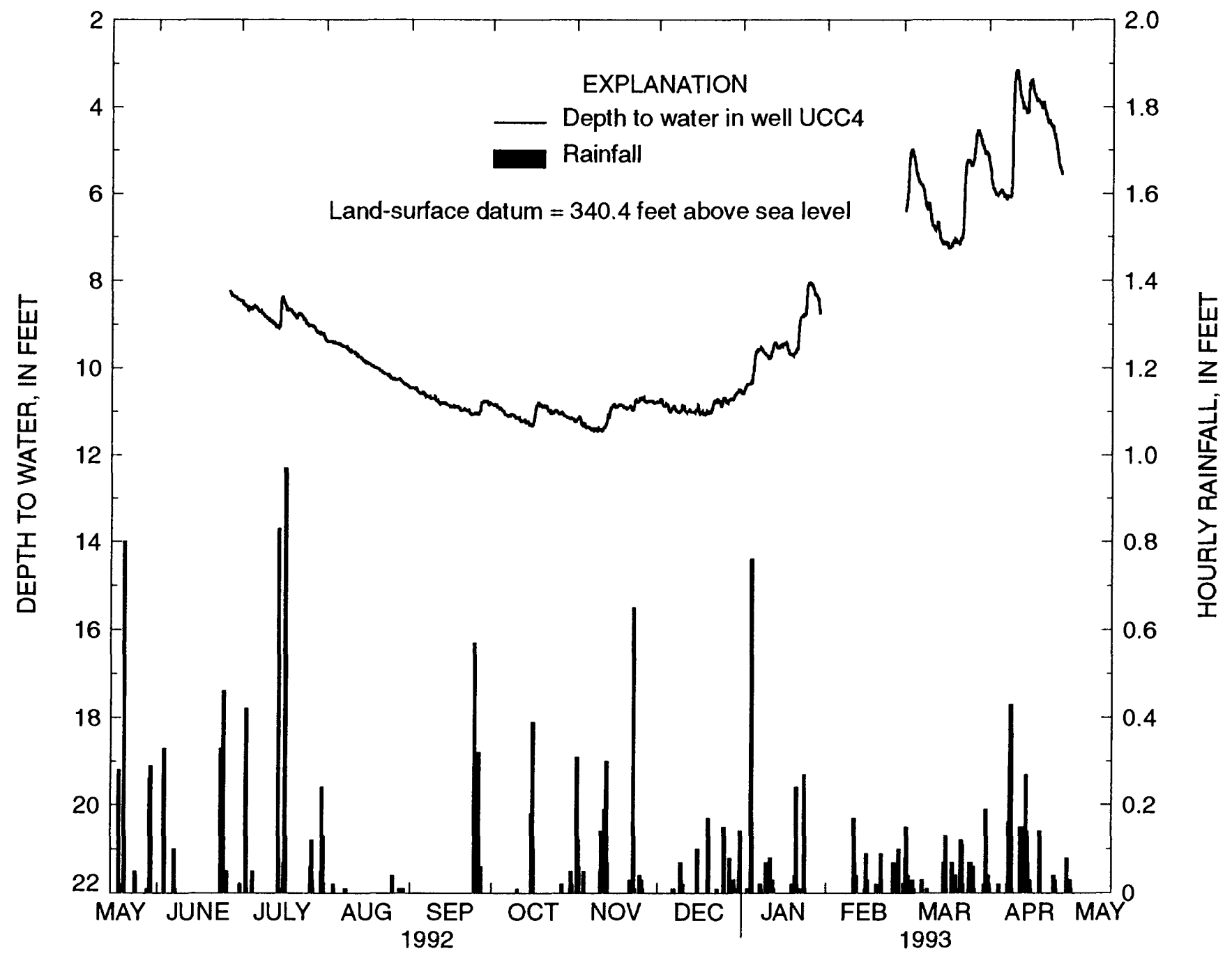

Figure 11. Depth to water in the McNairy Formation at well UCC4 and rainfall, Calvert City, Kentucky. 


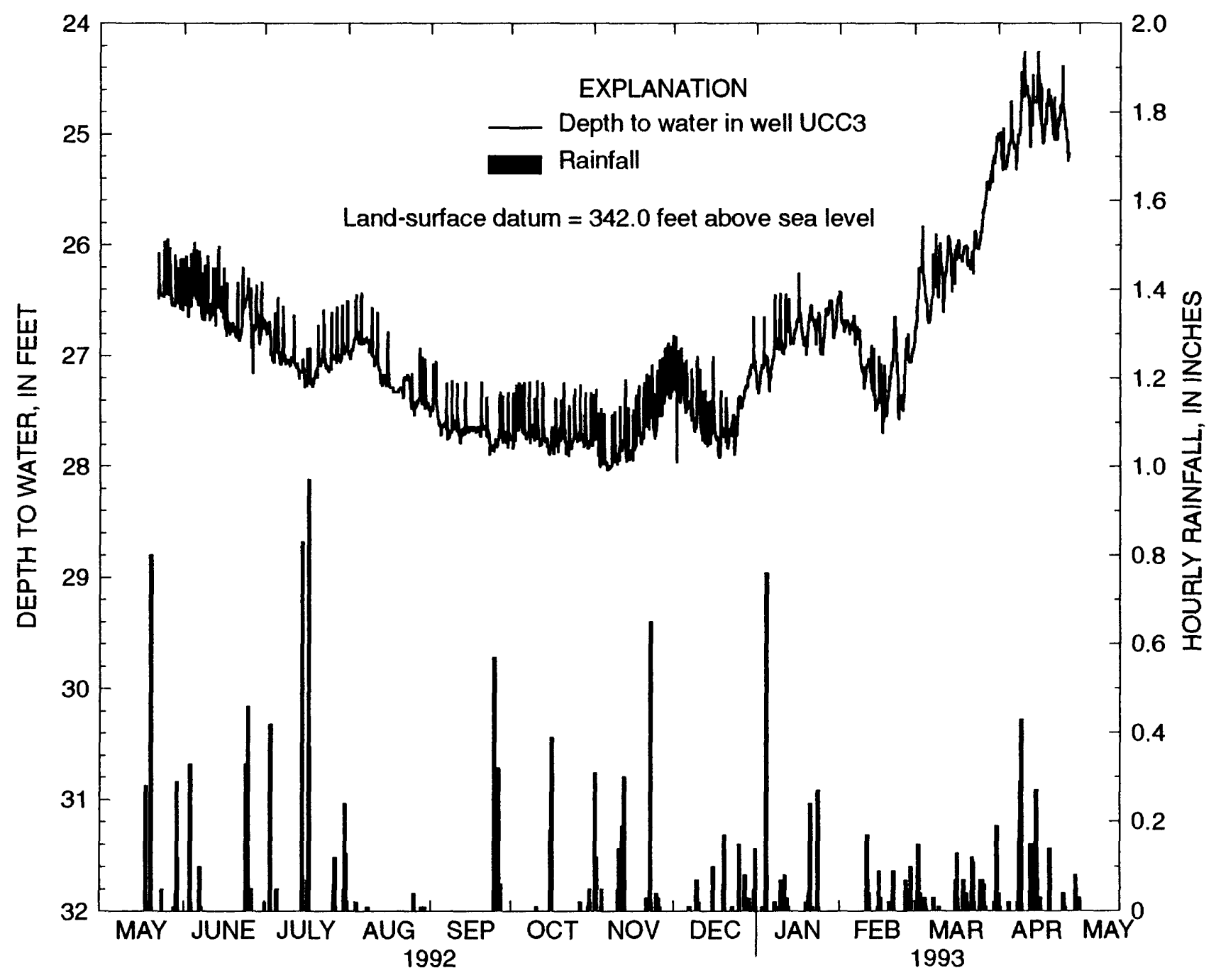

Figure 12. Depth to water in the alluvium at well UCC3 and rainfall, Calvert City, Kentucky. 


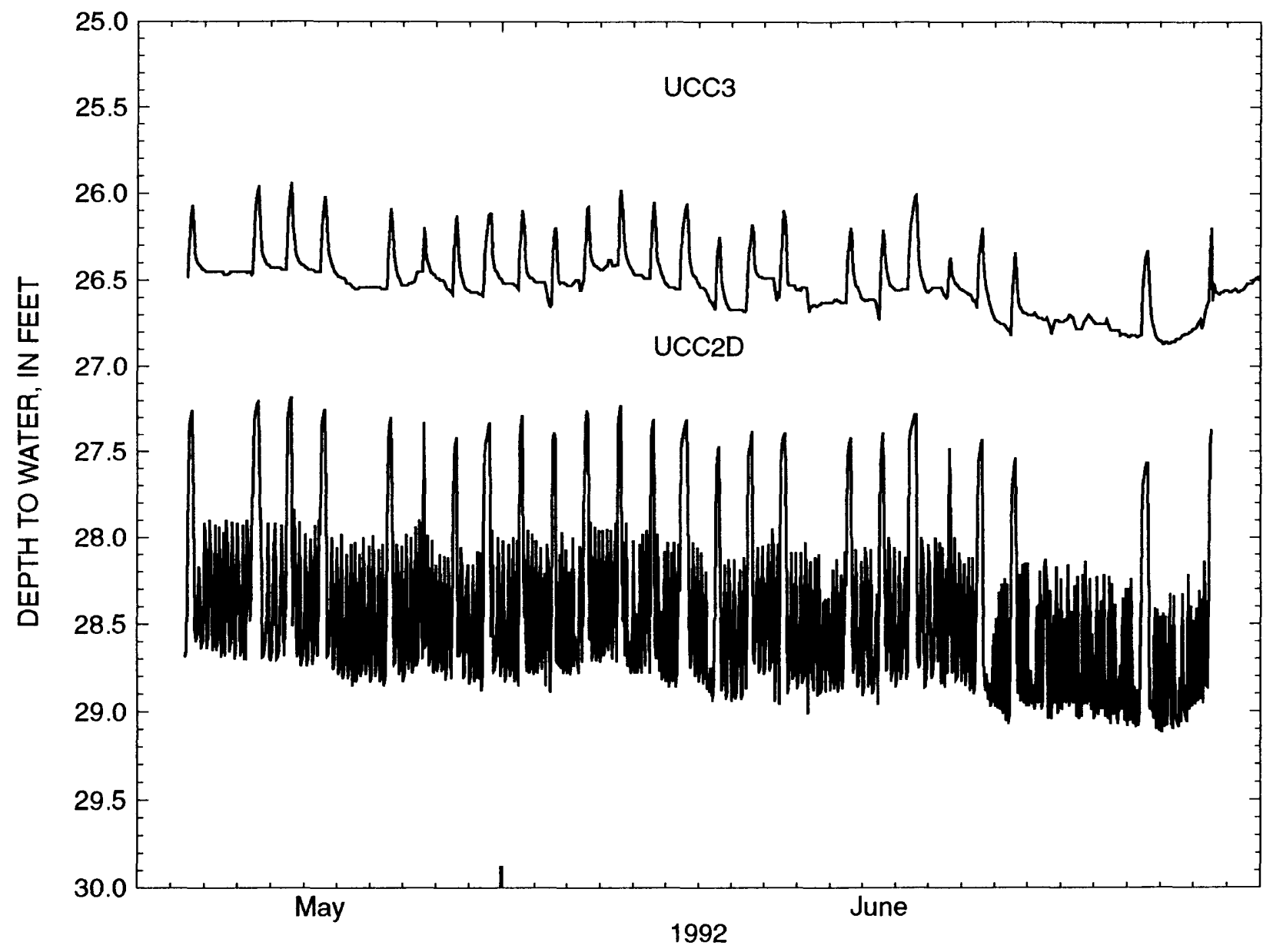

Figure 13. Selected water levels affected by ground-water withdrawal, Calvert City, Kentucky. 


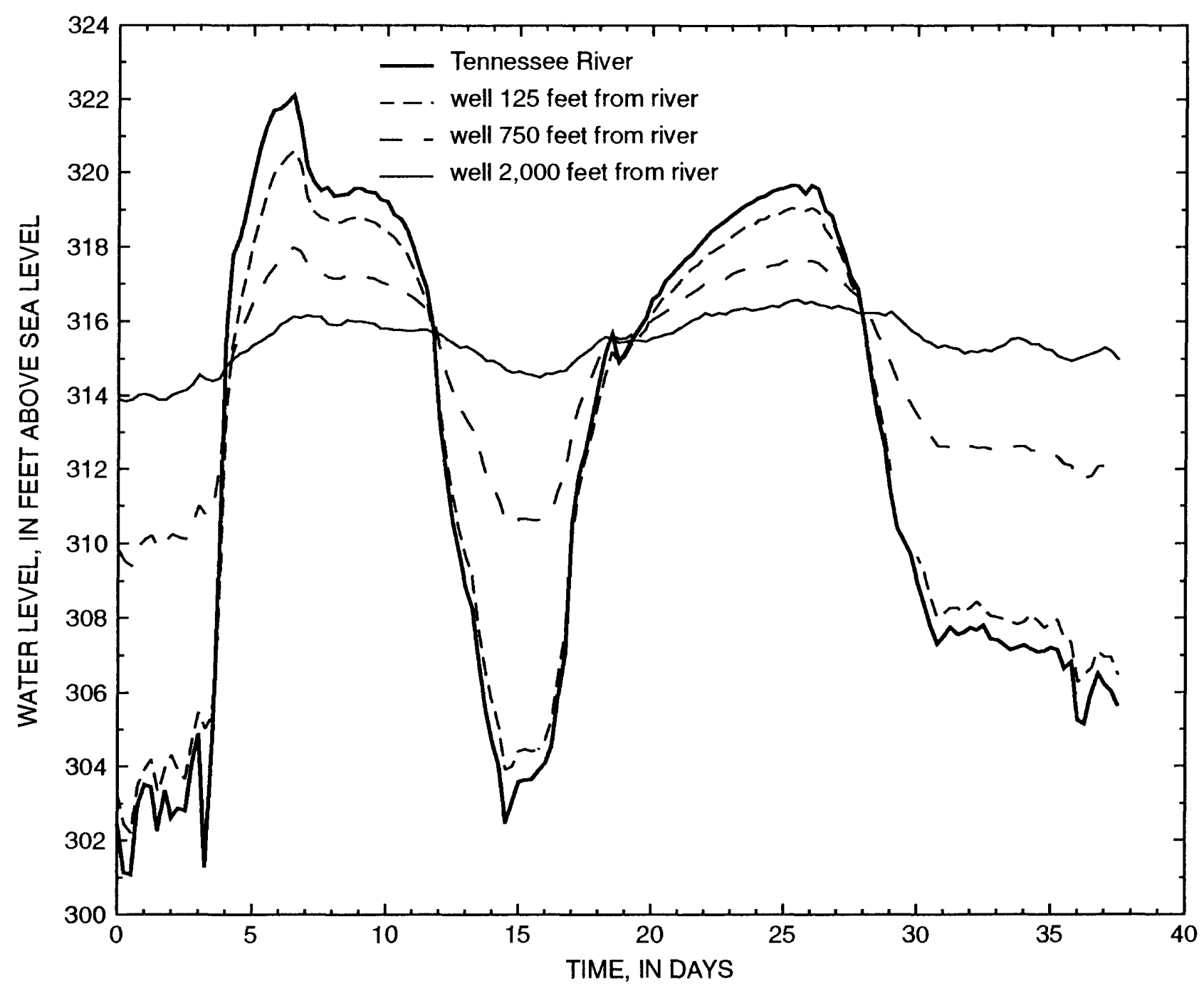

Figure 14. Selected water levels affected by river stage, Calvert City, Kentucky. (Modified from Dames and Moore, 1988b, fig. 8.) 


\section{Recharge}

Most recharge occurs south of Calvert City in the area underlain by the McNairy Formation (fig. 5) because this area is topographically higher and the surficial deposits are more permeable than in surrounding areas. Surficial deposits in this area include loess, continental deposits, or the McNairy Formation. Loess covers most hilltops and, based on its geologic description, probably diverts most rainfall to surface runoff down the hillsides where it can enter the aquifer through more permeable deposits. The extent to which recharge occurs through the loess, possibly through macropores and fractures, is unknown. The sand and gravel continental deposits, which underlie the loess and crops out on hillsides, allow greater infiltration of rainfall than does the loess. The McNairy Formation crops out on hillsides and valley bottoms (pl. 1) and rainfall or surface runoff can enter the aquifer through permeable sand layers. Where the McNairy Formation is represented by clay beds, infiltrating water forms local zones of perched water. Other than the extensive clay bed and perched water zone (fig. 6) already discussed, perched water is not considered further. Based on the geologic description of the upper unit of the alluvium, recharge from rainfall directly to the alluvium is less than recharge from rainfall to the McNairy Formation.

The timing and the approximate amount of recharge to the aquifer system is indicated on hydrographs. Based on hydrographs, recharge to the McNairy Formation occurred from January to April 1993 (fig. 11). Davis and others (1973) estimated the amount of recharge to the McNairy Formation to be 7.2 in. per year (in./yr). This estimate was made by multiplying the seasonal rise in water level in one well by the estimated specific yield of the aquifer. For the following reason, this method of analysis yields an estimate of recharge that is too low. By only considering the rise in water level, a constant water level implies no recharge; however, for water levels to remain constant, recharge must occur in the same amount as discharge from the aquifer system. The hydrograph analysis, applied to ground-water recharge, should include an estimate of the rate at which water levels would decline if there were no recharge.

Other sources of recharge include stage changes in the Tennessee River and water from Kentucky Lake that enters fractures and open joints in limestone. Recharge from high river stage is a short-lived phenomenon that dissipates after the stream stage returns to normal (fig 14); thus, the net recharge to the aquifer is zero. This phenomenon, known as bank storage, can be significant in terms of the quality of water (Starn, in press; Squillace and others, 1993). The impounding of water in Kentucky Lake caused water levels to rise in low-lying areas near the lake (Davis and others, 1973). This indicates that water moved from the lake into the aquifer through the fracture system; however, the distance from the lake over which the fractures are open is not known.

\section{Hydraulic Properties of the Aquifer System}

The hydraulic character of the lower alluvial unit was inferred from known well yields, lithologic description, and aquifer tests. Based on well-yield information, the lower unit of the alluvium is the most permeable unit of the aquifer system. The saturated thickness of the alluvium is 80 to $100 \mathrm{ft}$ and includes the middle unit of the alluvium. Based on the lithologic description, the horizontal permeability of the middle unit is much greater than the vertical permeability, so the middle unit probably forms a confining layer over the lower unit; however, some ground water probably leaks through the middle unit into the lower unit, particularly when the lower unit is pumped. Water-level data collected during pumping at the Calvert City Water Company support this concept. Two pairs of observation wells were installed near wells used for water supply at the Calvert City Municipal Water Company (fig. 7). One well of each pair was completed in the lower unit of the alluvial aquifer, and one well was completed in the middle unit (fig. 15). The pumps were turned off for 12 hours and water levels recovered to equal altitudes in all four wells. Pumping began at an unknown and variable rate (approximately $650 \mathrm{gal} / \mathrm{min}$ based on the requirements of the water treatment plant) and continued for 4 hours. The maximum drawdowns in deep 


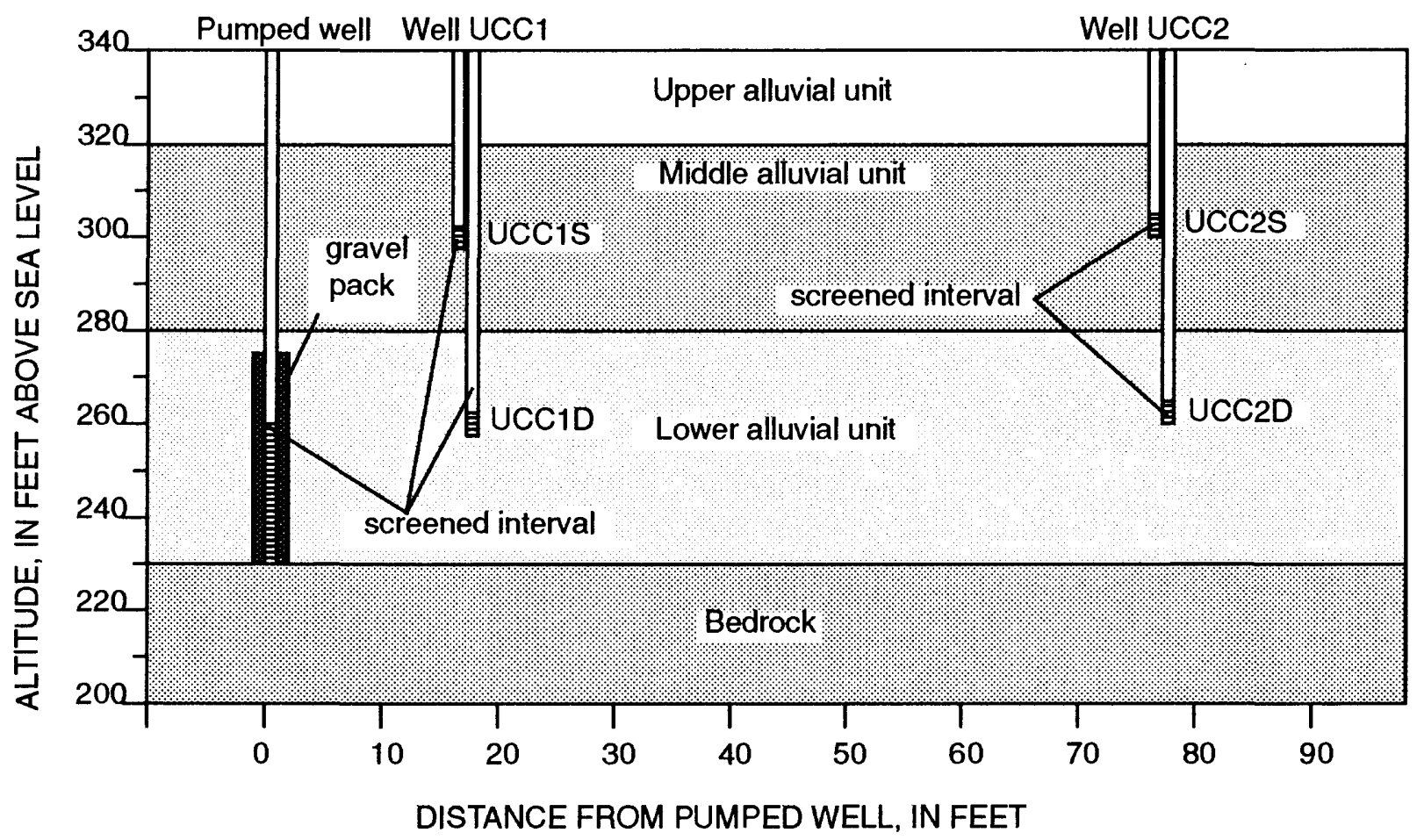

Figure 15. Generalized geologic section at the Calvert City Municipal Water Company, Calvert City, Kentucky. 
observation wells UCCID and UCC2D were $3.17 \mathrm{ft}$ and $0.72 \mathrm{ft}$, respectively. The corresponding drawdowns in the two shallow observation wells were $0.03 \mathrm{ft}$ and $0.02 \mathrm{ft}$, respectively. In this case, ground water flowed more freely to the well through the lower unit, although pumping had some affect on the middle unit.

Several previous investigators have determined the transmissivity of aquifers within the aquifer system. Davis and others (1973) reported aquifer tests at companies $\mathrm{C}$ and A. The values for transmissivity of the lower alluvial unit were $2,940 \mathrm{ft}^{2} / \mathrm{l}$ and $174,(00) \mathrm{ft}^{2} / \mathrm{d}$, respectively. The first value was affected by the lower saturated thickness of the aquifer near the Tennessee River (pl. 1). The second value may reflect the influence of localized transmissive faults in the limestone bedrock. A transmissivity of $5,0(0) \mathrm{ft}^{2} / \mathrm{d}_{\text {was }}$ used in a model of ground-water flow in the industrial complex (Dames and Moore, 1991). A transmissivity of $38,20\left(0 \mathrm{fi}^{2} / \mathrm{d}\right.$ was calculated at new wells used for water supply at the Calvert City Water Company (W.A. Tanner, Florence and Hutcheson Consulting Engineers, written commun., 1992). Transmissivity of the McNairy Formation $5.5 \mathrm{mi}$ south of the study area was calculated as $4,280 \mathrm{ft}^{2} / \mathrm{d}$ (Davis and others, 1973).

\section{Interaction of Ground Water and Cypress Creek}

The relation of Cypress Creek to the acpuifer system is best described by dividing the creek into three reaches, the boundaries of which are approximated (fig. 16). In the upper reach, Cypress Creek flows northward on top of the McNairy Fonnation. The gradient of the creek is low and the flow is sluggish; the upper reach is primarily a swampy lowland. In this reach, water flows from sands in the McNairy formation into Cypress Creck. In the middle reach, Cypress Creek flows onto the lacustrine sediments (the upper alluvial unit) and is incised into these predominantly clay and silt sediments that confine the creck to a narrow channel between steep banks. Also, in the middle reach, Cypress Creek is hydraulically separated from the aquifer system by the upper and possibly middle alluvial units. In the lower reach, the creek bed decreases in elevation in the downstream direction and is in direct connection with the aquifer in the lower alluvial unit.

The potentiometric surfaces indicated different flow patterns in the middle and lower units of the alluvium (Ron Yost; Fuller, Mossbarger, Scott, and May Consulting Engineers; written commun., 1989). Ground water flowed south toward Cypress Creek in the middle unit and flowed north to the Tennessee River in the lower unit. This flow patlem also was inferred from water levels in wells screened in the lower unit (wells UCC2 and UCC3) (figs. 12 and 13). The water levels fluctuated on the opposite side of Cypress Creek (fig. 13) in response to pumping at the Calvert City Municipal Water Company indicating that Cypress Creek is not a hydraulic barrier to flow and that ground water flows beneath Cypress Creek to the other side. The middle reach of Cypress Creek receives ground-water discharge from the middle unit of the alluvium, particularly during wet weather, but does not receive ground-water discharge from the lower alluvial unit.

Measurements of streamflow were made at four sites along Cypress Creek in May-June 1992 (fig. 16). The flow velocity in Cypress Creek was too low to measure using spinner-type flow meters except at constrictions such as bridge abutments; therefore, a detailed seepage study was not possible. There was less rainfall proceeding the streamflow measurement in June and this measurement better represents ground-water discharge to the creek at a point in time. The measurement at site CC-1 includes groundwater discharge to Cypress Creek from outside the aquifer system (fig. 6). The large increase in June streamflow between sites CC-2 and CC-3 $\left(0.068 \mathrm{ft}^{3} / \mathrm{s}\right.$ and $0.236 \mathrm{ft}^{3} / \mathrm{s}$, respectively) was caused by tributary flow. No tributaries enter Cypress Creek between sites CC-3 and CC-4 $\left(0.236 \mathrm{ft}^{3} / \mathrm{s}\right.$ and $0.353 \mathrm{ft}^{3} / \mathrm{s}$, respectively); the difference between the two $\left(0.117 \mathrm{ft}^{3} / \mathrm{s}\right)$ represents ground-water discharge from the middle and lower alluvial units to Cypress Creek. 

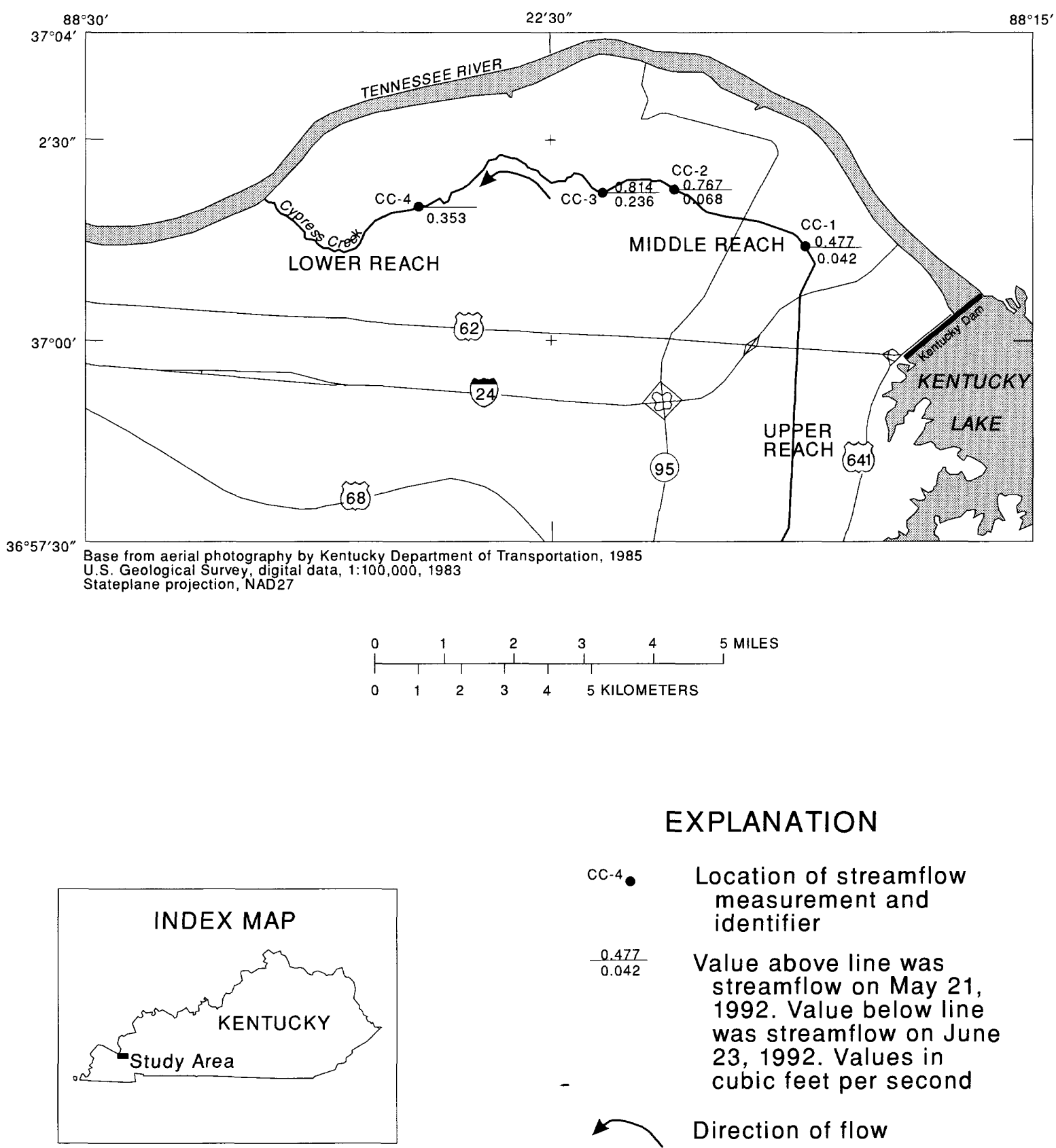

Figure 16. Streamflow measured in Cypress Creek, 1992. 


\section{SIMULATION OF GROUND-WATER FLOW}

The flow of ground water was simulated to estimate aquifer properties, the rate of recharge to the aquifer, the cont ributing areas to discharge boundaries, and the average lincar velocity at selected locations. The technique of simulation uses a mathematical model to predict the state of the system (hydraulic head and flow rates) from estimates of the hydraulic properties and boundary conditions of the aquifer system. The predicted state is then compared to the measured state of the system to assess the accuracy of the estimates. In this simulation, the hydrautic properties and boundary conditions of the aquifer werc represented by parameters in a nontinear regression. The regression adjusts the model parameters until differences between predicted and measured hydraulic heads and flow rates were minimized.

\section{Description of the Mathematical Model}

The governing partial-differential equation of two-dimensional, steady-state ground-water flow in a heterogeneous, isotropic, confined aquifer is

$$
\frac{\partial}{\partial x}\left(T \frac{\partial h}{\partial x}\right)+\frac{\partial}{\partial y}\left(T \frac{\partial h}{\partial y}\right)=W
$$

where

$T$ is the value of transmissivity along the $\mathrm{x}$ and $\mathrm{y}$ axes that are considered parallel to the major axes of hydraulic conductivity $\left(\mathrm{L}^{2} \mathrm{~T}^{-1}\right)$;

$h$ is the hydraulic head (L); and

$W$ is a volumetric flux per unit area and represents sources and (or) sinks of water $\left(\mathrm{LT}^{-1}\right)$.

Boundary conditions were selected to represent heads or flow rates at the edges of the model area. The governing equation and the boundary conditions were combined in a set of finite-difference equations and solved using the computer program MODFLOW (McDonald and Harbaugh, 1988). The parameters of the nonlinear regression were estimated using a method developed by Cooley and Naff (1990) and modified for use with MODFLOW by Hill (1992 and 1994). The combined ground-water flow model and nonlinear regression is called MODFLOWP.

\section{Model Grid and Layers}

The model grid (fig. 17) is 55 rows by 80 columns and extends to the natural hydrologic boundaries of the area; however, the main area of interest is near Calvert City and the Calvert City Industrial Complex. Cells in the area of interest are irregularly spaced with an average size of 300 by $300 \mathrm{ft}$. Cells outside the area of interest have a maximum size of 1,500 by $1,500 \mathrm{ft}$. Two island-like areas near Kentucky Lake (fig. 17) where unsaturated bedrock crops out are represented in the model grid by inactive grid cells. The natural hydrologic boundaries of the ground-water basin are the Tennessee River, Kentucky Lake, and ground-water divides. Ground-water divides were represented by no-flow boundaries. The no-flow boundary on the southern edge of the model grid was defined by the ground-water divide beneath the area of perched water (fig. 6). This boundary also coincides with surface drainage boundaries. The no-flow boundary on the southwestern edge separates the ground-water basins that discharge into the Tennessee 


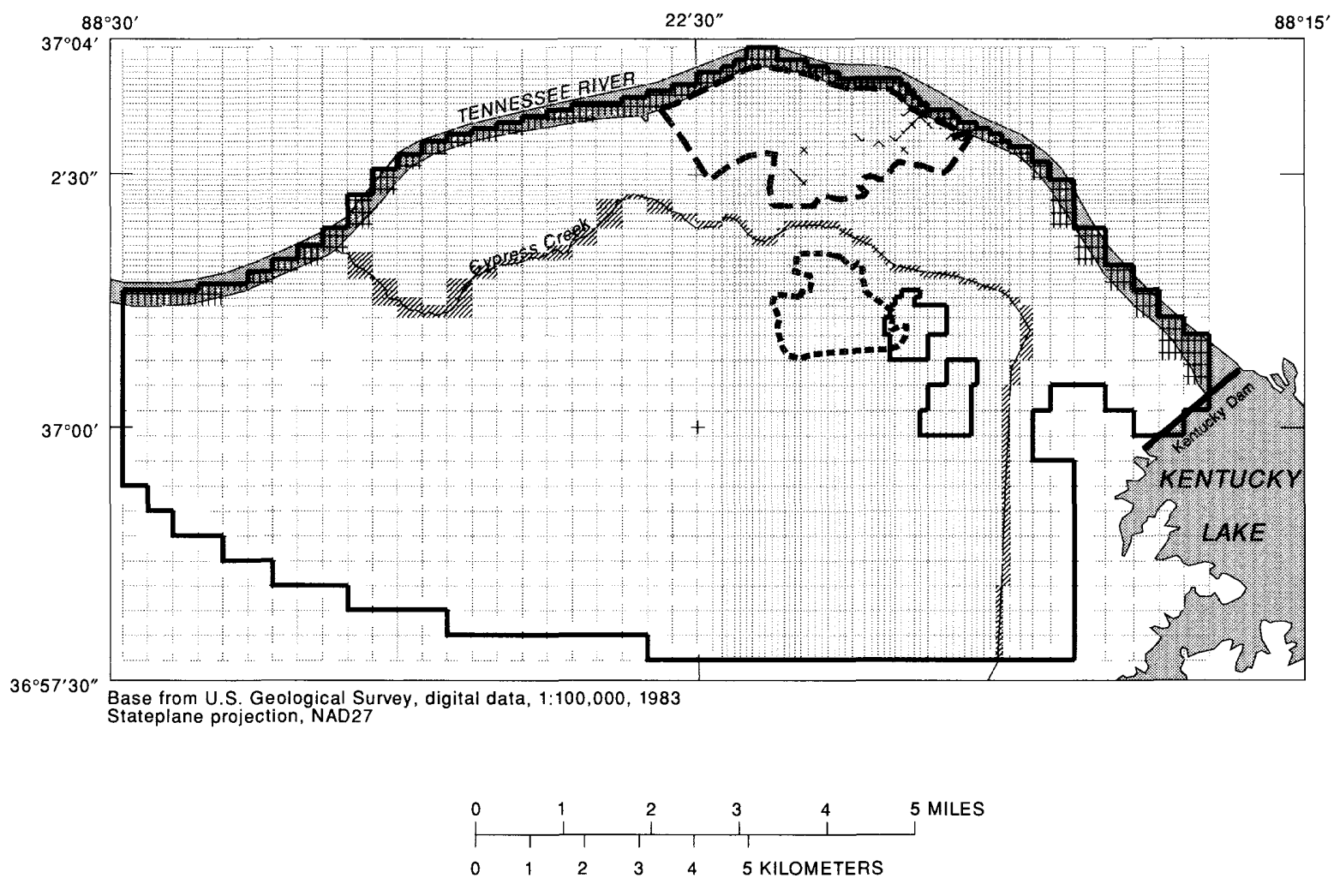

\section{EXPLANATION}
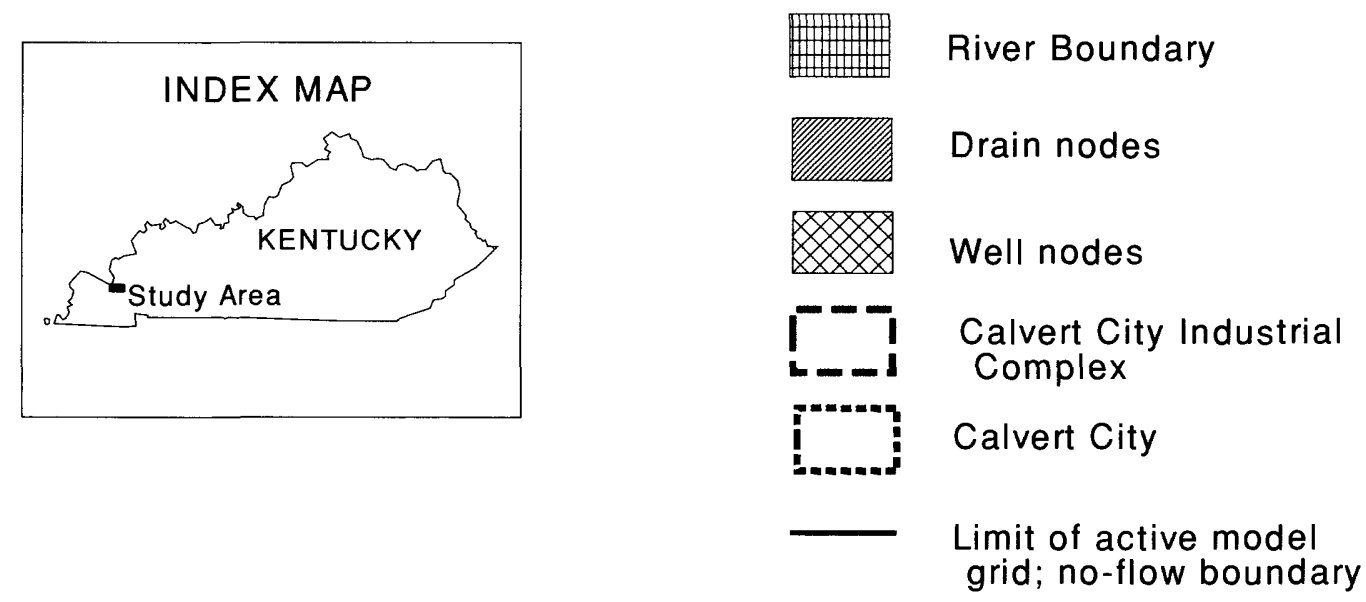

Figure 17. Extent of model grid and model boundary conditions. 
River and East Fork Clarks River. The affect of Kentucky Lake on the flow system was unknown, so this boundary was simulated in altemative models as a constant-head and a no-flow boundary. The base of the aquifer system below the fractured and weathered limestone bedrock was simulated as a no-flow boundary.

The aquifer system, although modeled as a single layer, comprises two geologic layers: an upper layer of unconsolidated sediments and an underlying layer of weathered and fractured limestone bedrock and limestone residuum (fig. 5). In zone 1 (fig. 18), the aquifer in the upper layer is in sands in the McNairy Formation. In zone 2, the aquifer in the upper is in the lower alluvial unit. Variations in thickness of the aquifer were included in the model by use of a multiplication matrix, the values of which were computed from bedrock altitude (Amos and Wolfe, 1966; Amos and Finch, 1968) and the average altitude of the top of the aquifer. The hydraulic properties of the upper bedrock were not known, but were considered to be similar to the unconsolidated sediments on the basis of water-level data and geologic description.

\section{Boundary Conditions and Source Terms}

Boundary conditions and source and (or) sink terms are incorporated in MODFLOW through separate modules called packages (McDonald and Harbaugh, 1988). In this simulation the river, drain, generalhead, recharge, and well packages were used. The river, drain, and general-head packages calculate flow into the aquifer by multiplying the head difference between an outside source of water (such as a river) and the aquifer by the conductance. The conductance, defined below, is calculated by the model depending on the type of boundary. Conductance is defined as

$$
C=(K A) / M
$$

where

$C \quad$ is the conductance of the model cell representing the boundary $\left(\mathrm{L}^{2} \mathrm{~T}^{-1}\right)$;

$K \quad$ is the hydraulic conductivity between the source of water and the model cell $\left(\mathrm{LT}^{-1}\right)$;

$A \quad$ is the area of the boundary in the model cell $\left(\mathrm{L}^{2}\right)$; and

$M \quad$ is the distance from an outside source of water to the boundary (L).

The recharge and well packages add water to a model cell at a specified rate. Recharge is calculated as a linear rate of flow $\left(\mathrm{LT}^{-1}\right)$ that the model multiplies by the area of the cell. The well package uses the volumetric rate of ground-water withdrawal $\left(\mathrm{LT}^{-3}\right)$, which was considered to be known and free of error.

The Tennessee River was simulated using the river package and the leakance (hydraulic conductivity divided by thickness) of the riverbed was estimated as a parameter in the regression. The river package allows flow to or from the river. The leakance of the riverbed was multiplied by the area of the river in each cell to calculate the conductance of the riverbed. The area of the riverbed in each cell was calculated by overlaying the grid on a map of the river.

Cypress Creek was simulated using the drain package and the conductance of this boundary was estimated as a parameter. The drain package only allows flow into the drain. If the calculated water level was below the altitude of the base of the creek, the boundary did not affect the model; thus, the point of intersection between the creek bed and the aquifer was determined in the model. 

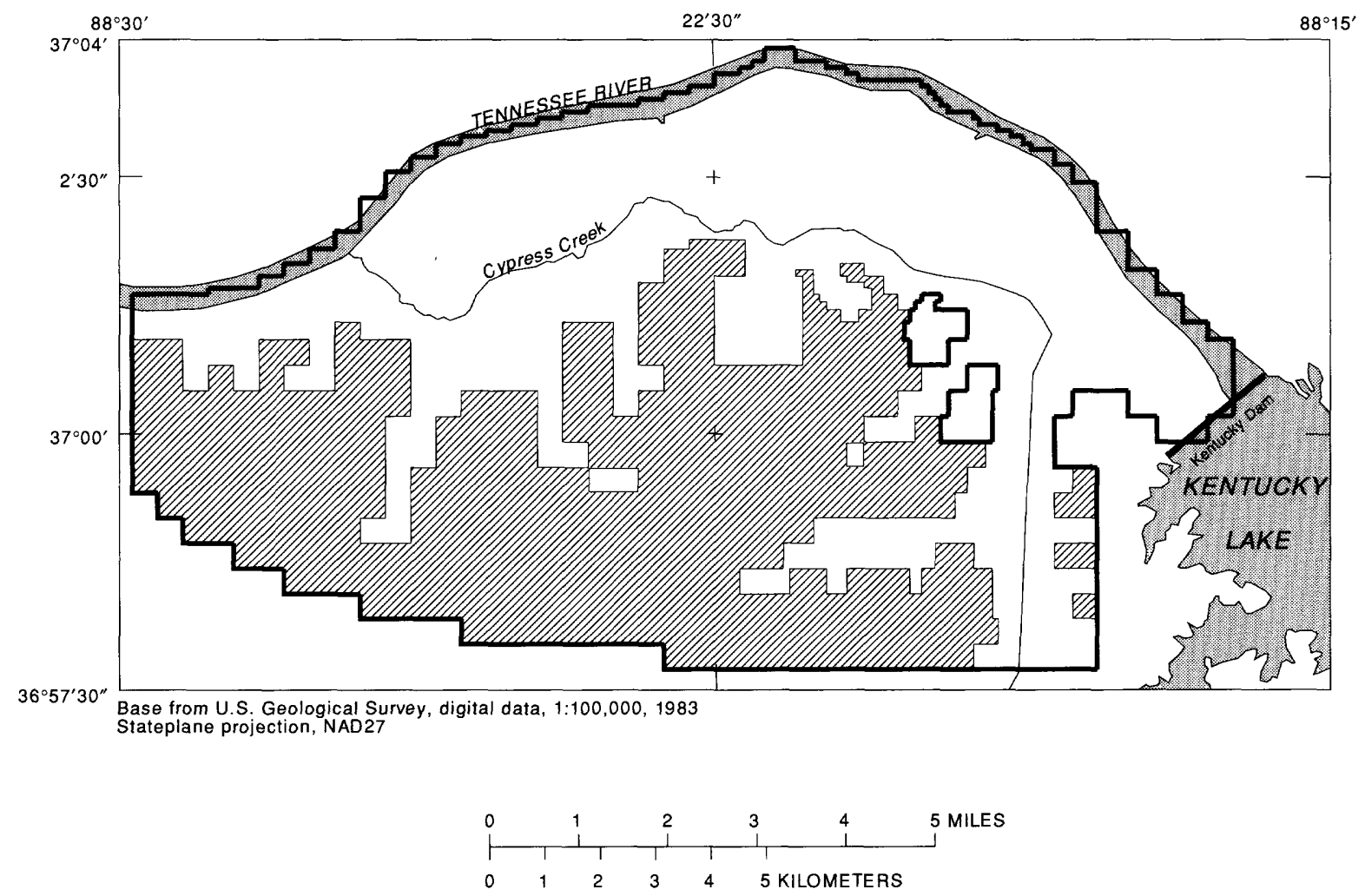

\section{EXPLANATION}
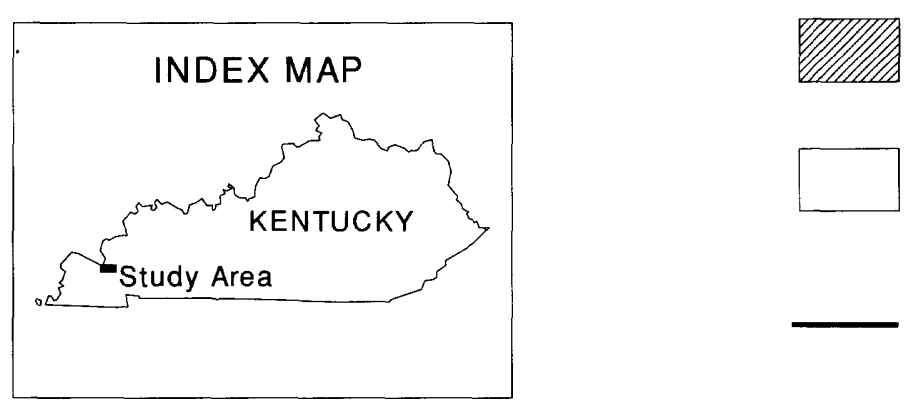

Zone 1--Cells used in definition of recharge and transmissivity that correspond to alluvium

$\square$ Zone 2--Cells used in definition of recharge and transmissivity that correspond to the McNairy Formation

Limit of active model grid; no-flow boundary

Figure 18. Parameter zones used in model. 
Recharge to the lower alluvial unit from the middle alluvial unit was simulated using the general-head package and the conductance of this boundary was estimated as a parameter. This package allows flow to or from the boundary. The head in the middle alluvial unit was considered to be constant at $325 \mathrm{ft}$ based on limited water-level data collected in June 1992. In reality, head in the middle alluvial unit was probably not constant, so this assumption is a source of uncertainty in the model. Recharge to the alluvium also was modeled as a specified flow in an altemative model discussed later in this report.

Recharge to the McNairy Formation was simulated using the recharge package and the rate of recharge was estimated as a parameter. Flow from the boundary in this package is an areally distributed quantity that does not depend on head in the aquifer; it depends on factors such as rainfall, soil type, and topography. The parameter is an estimate of the average over zone 1 and does not include differences between recharge from sand and gravel or from loess. Recharge to the McNairy Formation from Kentucky Lake was simulated as a constant-head boundary in an alternative model.

\section{Model Calibration}

The model was calibrated to 55 head measurements and 3 streamflow measurements made in June 1992 that represent average flow conditions. Many of the 157 original head measurements were omitted from the calibration data set because (1) they were made in wells completed in shallow zones above the main aquifer system, (2) there was recent pumping in or near the well, or (3) because there was a large number of wells in a small area, as was the case with observation wells in the industrial complex. Hydrographs (figs. 11 and 12) indicated that June 1992 marked the end of seasonal recharge to the aquifer system and the beginning of the gradual decline in water levels as the aquifer system drained; therefore, based on this limited evidence, the water levels in June 1992 were assumed to approximate mean annual water levels.

Streamflow measurements were used to compute gains in streamflow along Cypress Creek (fig. 16). Flow to Cypress Creek at CC-1 $\left(0.042 \mathrm{ft}^{3} / \mathrm{s}\right)$ included streamflow from a drainage area outside the model area (fig. 5). The contribution from within the model area was estimated to be one-half the measured flow $\left(0.021 \mathrm{ft}^{3} / \mathrm{s}\right)$ based on the approximately equal sizes of the two drainage areas. Between CC-2 and CC-3 the flow to Cypress Creek was from tributary flow and was not included in the calibration data set. The difference between CC-3 and CC-4 $\left(0.117 \mathrm{ft}^{3} / \mathrm{s}\right)$ was equal to the ground-water discharge to Cypress Creek in this reach. It was assumed that this value mainly represented contributions to discharge from the lower alluvial unit and not the middle alluvial unit, which was not simulated in the model.

\section{Calibration Procedure}

Ground-water flow models are typically calibrated by the trial-and-error method, in which a series of adjustments to the model is made until a reasonable match between calculated and observed heads and flows is produced. Nonlinear regression makes calibration more efficient and objective by adjusting parameters automatically, using the response of the model to changes in parameter values as a guide, until the weighted sum-of-squares error (SSE) is minimized. The statistical framework of this process can be used to determine the validity of the regression, the reliability of the parameter estimates, and the likelihood that a given model more accurately represents the system than an alternative model. The method is described by Cooley and Naff (1990) and Hill (1992 and 1994). 
The nonlinear regression minimizes the weighted SSE, given by

$$
S S E=\sum_{i=1}^{n}\left(w_{i}^{1 / 2} e_{i}\right)^{2}
$$

where

$e_{i} \quad$ is the difference between the observed and calculated values of measurement $i(\mathrm{~L})$;

$w_{i}^{1 / 2}$ is the square root of the weight assigned to the error in the observed value of measurement $i(\mathrm{~L})$; and

$n \quad$ is the number of observations.

Weights were defined and calculated according to procedures in Hill (1992) to account for measurement error in the observed values and for the difference in units between heads and flows ( $\mathrm{ft}$ and $\mathrm{ft}^{3} / \mathrm{d}$, respectively). Weights of the heads and flows were calculated as $\sigma^{2} / \sigma^{2}$, where $\sigma^{2}$ was the common error variance and $\sigma^{2}$ was the variance of measurement error of the $i$ th head or flow. Measurement errors for heads and flows were considered to be normally distributed. The standard deviations (the square root of the variance) of measurement errors were considered to be equal to the accuracy of the measurement, stated below, divided by the critical value at the 95-percent confidence interval (1.96). The accuracy of head measurements was considered to he the accuracy of the altitude of the measuring point, which was $1 \mathrm{ft}$ for surveyed altitudes and $5 \mathrm{ft}$ for altitudes estimated from a 1:24,000-scale topographic map. The accuracies of each streamflow measurement, which were between 5 and 10 percent, were added to obtain the accuracies of gains in streamflow. The common error variance must equal the error variance computed by the model, so the final step in model calibration was to set the common error variance equal to the computed error variance. This procedure did not change weights of the heads, but did change weights of the flows. The common error variance used in the final model was $9.27 \mathrm{ft}^{2}$.

The abbreviations used for parameters are listed in table 1 . Not all parameters were estimated in every model; some parameters were estimated in alternative models. All parameters except recharge were estimated as their log-transformed values, which ensured that the parameter value was always positive. The criteria to determine the final parameter set were (1) parameter estimation converged, (2) the weighted SSE was minimized, (3) correlation between parameters was minimized, (4) variance of the estimates was minimized, and (5) as many parameters were estimated as possible. Satisfying all these criteria simultaneously generally was not possible and some judgment was required to determine the set of parameters that was finally estimated in the calibrated model. Parameters of the calibrated model were T1, T2, RCH1, KRB, KDR, and GHB1. 
Table 1. Model parameters estimated using nonlinear regression, Calvert City, Kentucky

\begin{tabular}{ll}
\hline \multicolumn{1}{c}{ Parameter } & Abbreviation \\
\hline Transmissivity of the McNairy Formation & $\mathrm{T} 1$ \\
Transmissivity of the lower alluvial unit & $\mathrm{T} 2$ \\
Transmissivity of faults in the bedrock & $\mathrm{T} 3$ \\
Recharge to the McNairy Formation & $\mathrm{RCH} 1$ \\
Recharge to the lower alluvial unit & $\mathrm{RCH} 2$ \\
Leakance of the riverbed & $\mathrm{KRB}$ \\
Conductance of the bed of Cypress Creek & $\mathrm{KDR}$ \\
Conductance of the general-head recharge boundary over the alluvium & $\mathrm{GHB} 1$ \\
\hline
\end{tabular}

\section{Estimates of Model Parameters}

The optimal parameter values obtained from nonlinear regression (table 2) were close to expected values. The estimated transmissivities were within the range of reported values. The transmissivity of the McNairy Formation was expected to be lower than the transmissivity of the lower alluvial unit; however, they were estimated to be almost equal. Although the hydraulic conductivity of the lower alluvial unit is probably higher than of individual sand beds of the McNairy Formation, the McNairy Formation can be thicker; therefore, the transmissivity of the two aquifers, which is the product of hydraulic conductivity and aquifer thickness, can be similar.

Table 2. Optimal parameter values obtained from nonlinear regression, Calvert City, Kentucky

$\left[\mathrm{ft}^{2} / \mathrm{d}\right.$, square feet per day; ft/d, feet per day]

\begin{tabular}{lcl}
\hline Parameter & Estimate & Units \\
\hline T1 & 19,000 & $\mathrm{ft}^{2} / \mathrm{d}$ \\
T2 & 20,000 & $\mathrm{ft}^{2} / \mathrm{d}$ \\
KDR & 143 & $\mathrm{ft}^{2} / \mathrm{d}$ \\
KRB & .00592 & $\mathrm{~d}^{-1}$ \\
RCH1 & .00269 & $\mathrm{ft} / \mathrm{d}$ \\
GHB & .391 & $\mathrm{ft}^{2} / \mathrm{d}$ \\
\hline
\end{tabular}

The rate of recharge to the lower alluvial unit was much lower than recharge to the McNairy Formation. Although recharge to the lower alluvial unit was simulated as a general-head boundary, the quantity of interest was the average rate of recharge. The rate of recharge to the alluvium was $0.000484 \mathrm{ft} / \mathrm{d}(2.1 \mathrm{in} . / \mathrm{yr})$ under simulated conditions. This rate would change if head in the aquifer 
changed, as would occur if pumping increased or decreased. The rate of recharge to the McNairy Formation was expected to be higher than $7 \mathrm{in./yr}$ (Davis and others, 1973) as discussed in the section on recharge. The rate of recharge to the McNairy Formation was $0.00269 \mathrm{ft} / \mathrm{d}(11.8 \mathrm{in} . / \mathrm{yr})$.

Previous estimates of streambed leakance were not available, but geologic descriptions of the texture and thickness of the deposits can be used to determine a reasonable value. The riverbed is composed of sands with lenses of organic-rich fine material and is an average of $20 \mathrm{ft}$ thick (Dames and Moore, 1991). In vertical flow through layers, the hydraulic conductivity of the sequence is dominated by the least permeable layer; therefore, the mean vertical hydraulic conductivity of silt from 39 samples reported by Morris and Johnson (1967), $0.08 \mathrm{ft} / \mathrm{d}$, was used to compute a reasonable leakance value. Dividing $0.08 \mathrm{ft} / \mathrm{d}$ by the average thickness yields a reasonable estimate of leakance of $0.004 \mathrm{~d}^{-1}$. The range of reasonable vertical hydraulic conductivity is large considering the limited data available for the site, but the modelcalculated value of $0.00592 \mathrm{~d}^{-1}$ seems reasonable.

\section{Hydraulic-Head Distribution}

The values of hydraulic head computed by the calibrated model (fig. 19) were similar to those observed. The apparent difference with the observed June 1992 potentiometric surface (fig. 10) in the upper reach of Cypress Creek was because of the coarseness of the model grid. The hydraulic gradient on either side of the upper reach of Cypress Creek was steep and occurred within a model cell; thus, contours based only on calculated heads at cell centers did not show the effects of ground-water discharge to Cypress Creek.

The model should not be biased; that is, it should not systematically overpredict or underpredict head. Based on their distribution, the weighted residuals seem to be unbiased (fig. 20). The weighted residuals ranged from -9.92 to $8.4 \mathrm{ft}$. Only five values were less than $-5 \mathrm{ft}$ or greater than $5 \mathrm{ft}$ and 71 percent of all weighted residuals were between -3 and $3 \mathrm{ft}$. The residuals also were plotted (fig. 21) on a map to determine if there was a spatial bias in the model. The weighted residuals of the calibrated model seem randomly distributed over the modeled area with the exception of the western part of the modeled area north of Cypress Creek. In this area, there was a tendency for the model to overpredict head. This could be a result of unknown variation of aquifer properties that was not simulated.

For the regression to be valid, the distribution of the weighted residuals should resemble a standard normal distribution. The correlation coefficient between the ordered weighted residuals and random independent, normal deviates was used to test for independent, normally distributed weighted residuals (Hill, 1992). The critical value of the correlation coefficient at the 5-percent significance level is 0.961 . The correlation coefficient computed from the regression, 0.965 , was greater than the critical value and the residuals were considered to result from a random normal distribution.

\section{Rate of Flow}

Flow to the upper reach of Cypress Creek was calculated to be $0.00251 \mathrm{ft}^{3} / \mathrm{s}$ compared to an estimated flow of $0.00211 \mathrm{ft}^{3} / \mathrm{s}$; thus, the calculated flow was 19 percent too high. Flow to the lower reach of Cypress Creek between measurement sites CC-3 and CC-4 (fig. 16) was calculated to be $0.116 \mathrm{ft}^{3} / \mathrm{s}$ compared to a measured flow of $0.117 \mathrm{ft}^{3} / \mathrm{s}$. The model predicted, as expected, that ground water did not discharge from the aquifer to the middle reach of the creek. The total rate of flow to Cypress Creek for the calibrated model was $0.597 \mathrm{ft}^{3} / \mathrm{s}$, most of which occurred downstream of measurement site CC- 4 . The total flow of ground water to the Tennessee River computed by the calibrated model was $22.3 \mathrm{ft}^{3} / \mathrm{s}$. 

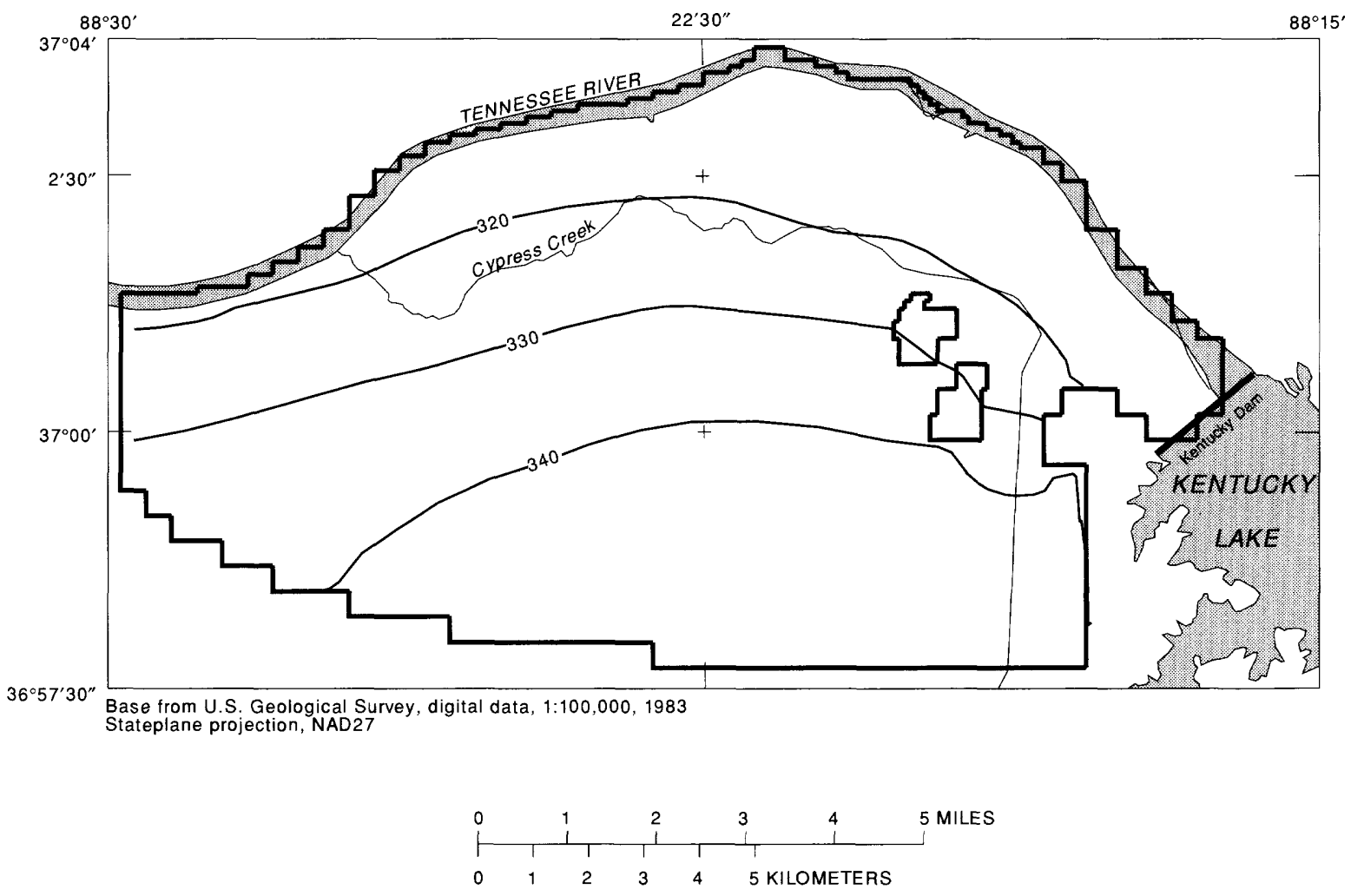

\section{EXPLANATION}

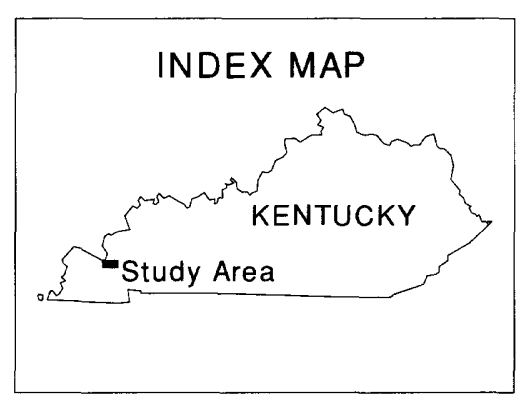

-320- CALCULATED POTENTIOMETRIC CONTOUR--Shows altitude at which water would have stood in tightly cased wells, June 1992. Countour interval 10 feet. Datum is sea level.

Limit of active model grid; no-flow boundary

Figure 19. Potentiometric surface calculated with the calibrated model. 


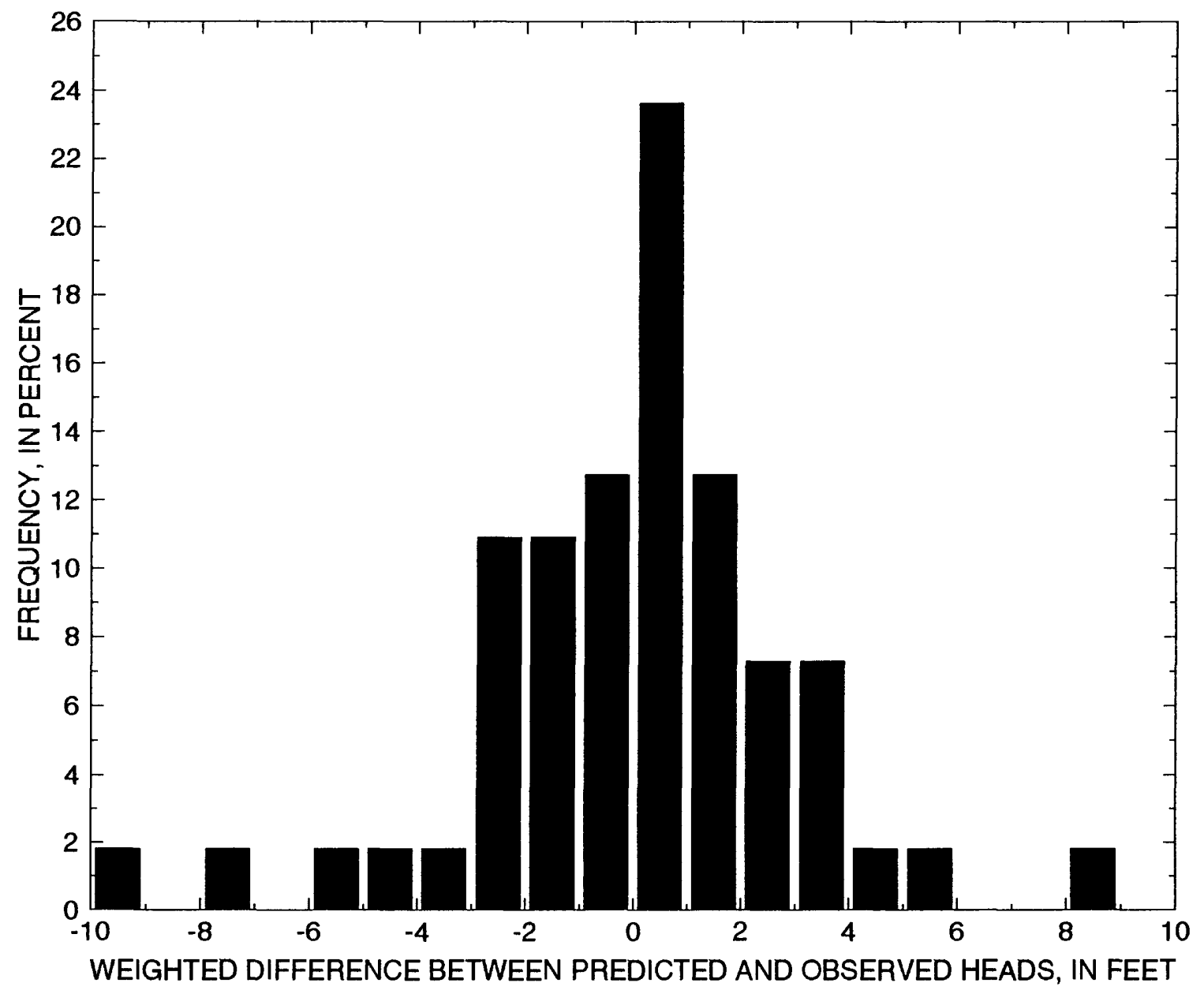

Figure 20. Weighted differences between calculated and observed heads, Calvert City, Kentucky. 

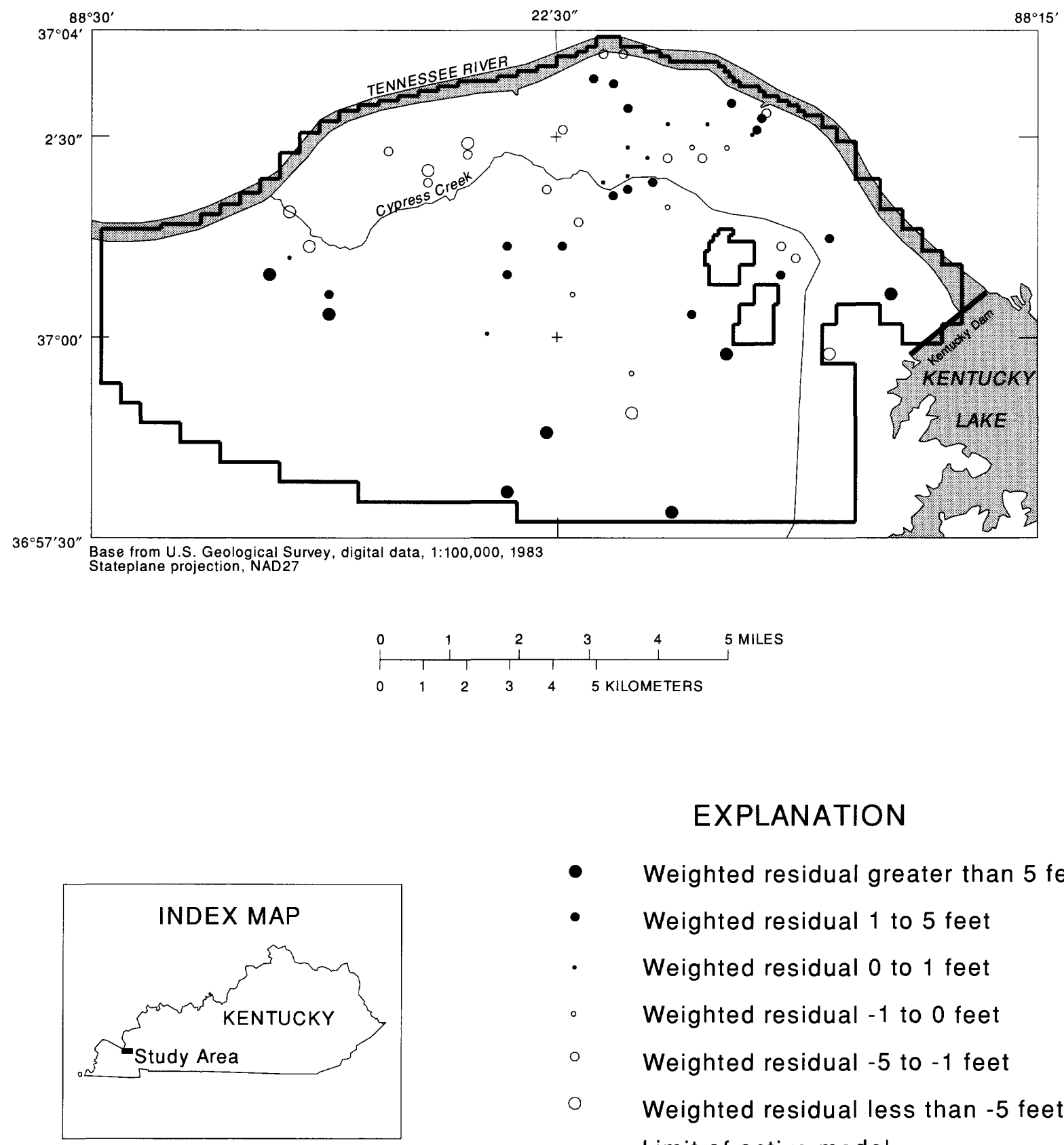

\section{EXPLANATION}

- Weighted residual greater than 5 feet

- Weighted residual 1 to 5 feet

- Weighted residual 0 to 1 feet

-Weighted residual -1 to 0 feet

$\circ \quad$ Weighted residual -5 to -1 feet

$0 \quad$ Weighted residual less than -5 feet

Limit of active model

grid; no-flow boundary

Figure 21. Spatial distribution of weighted residuals. 


\section{Alternative Models}

Values of the parameters of the calibrated model cannot be changed without increasing the SSE; therefore, if an improvement to the model is desired, the number of parameters, the size and shape of parameter zones, or model design must be changed. Although the calibrated model was a reasonable representation of flow in the aquifer, four other plausible models were posed to determine if they were hetter than the calibrated model. A particular model can be demonstrated to be hetter than alternative models, but it cannot be proven to he the best model. The size and shape of parameter zones were based on geologic maps and were considered to he correct, so altemative models were created by changing how boundaries were represented and by adding additional geologic features.

Two of the alternative models were used to test different representations of houndary conditions. In altemative model CAL0, recharge to the alluvium was simulated as a specified-flow boundary; in other words, the amount of recharge did not depend on head in the aquifer. The model CAL1 was the calibrated model, with recharge to the alluvium represented as a head-dependent flow. Kentucky Lake supplies water to wells near Kentucky Lake through weathered bedrock. To simulate the possible effect of Kentucky Lake as a source of water to the aquifer system in areas not near the lake, CAL2 was modified from CAL1 by representing the lake as a constant-head boundary.

Two alternative models simulated the effects of change in transmissivity in the aquifer system. Several faults that could hypothetically represent zones of high transmissivity relative to the surrounding alluvium underlay the area (fig. 4). A well at ISP that was used in an aquifer test to compute an anomalously high transmissivity of $174,000 \mathrm{ft}^{2} / \mathrm{d}$, is near a fault. To test the possibility that the fault is transmissive, a third transmissivity zone (T3) along the fault was simulated in the alternative models CAL3 and CAL4. In CAL3, recharge to the alluvium was a specified flow ( $R C H 2)$. In CAL4, recharge to the alluvium was a head-dependent flow. Neither CAL3 nor CAL4 included a constant-head boundary at Kentucky Lake.

Parameters for the altemative models were estimated through the regression procedure (table 3). The alternative models were compared using the SSE that was computed by MODFLOWP. In some circumstances, smaller values of the SSE indicate better models (Hill, 1992). On this basis, models that simulate head-dependent recharge to the alluvium (CAL1 and CAL4) are better models than the others. Residuals from the altemative models are similar, indicating that in general the altemative models have the same source of model uncertainty as the calibrated model. Correlation between parameters was similar in the alternative models. In all models tested, recharge to the McNairy Formation and the transmissivity of the alluvium have a correlation coefficient of greater than 85 percent.

Water budgets computed by the regression procedure for the altemative models are presented (table 4) to illustrate their differences. Total flow through the aquifer was 2.31 to $2.78 \mathrm{Mgal} / \mathrm{d}$ in all alternative models. When transmissive faults were simulated (CAL3 and CAL4), there was less recharge to the lower alluvial unit because pumping wells were able to capture water from a larger area. When recharge to the lower alluvial unit was treated as a head-dependent boundary (CAL1 and CAL4), the average rate of recharge was less than when it was treated as a specified flow (CAL 0 and CAL3). In CAL1 and CAL4, more water was supplied near pumping wells - the head difference between the aquifer and the external source of water was greater-and the average rate of recharge was not increased hy the regression to compensate, as was the case in CALO and CAL3. The regression procedure adjusted parameters of the alternative models so that lower recharge correlated with lower flow to the Tennessee River, rather than as less flow to Cypress Creek. 
Table 3. Parameter values for alternative models computed by nonlinear regression, Calvert City, Kentucky [CAL, calibration; ft2/d, square feet per day, NE, not estimated; $d-1$, inverse days; $f / d$, feet per day: CAL1 is calibrated model]

\begin{tabular}{lccccc}
\hline Parameter & CAL0 & CAL1 & CAL2 & CAL3 & CAL4 \\
\hline $\mathrm{T} 1, \mathrm{ft}^{2} / \mathrm{d}$ & 21,000 & 19,000 & 32,000 & 19,000 & 17,000 \\
$\mathrm{~T} 2, \mathrm{ft}^{2} / \mathrm{d}$ & 26,000 & 20,000 & 17,000 & 22,000 & 18,000 \\
$\mathrm{~T} 3, \mathrm{ft}^{2} / \mathrm{d}$ & $\mathrm{NE}$ & $\mathrm{NE}$ & $\mathrm{NE}$ & 270,000 & 160,000 \\
$\mathrm{GHB}, \mathrm{ft}^{2} / \mathrm{d}$ & $\mathrm{NE}$ & .391 & .0874 & $\mathrm{NE}$ & .376 \\
$\mathrm{KDR}, \mathrm{ft}^{2} / \mathrm{d}$ & 114 & 143 & 48 & 113 & 144 \\
$\mathrm{KRB}, \mathrm{d}^{-1}$ & .00592 & .00564 & .00258 & .00436 & .00504 \\
$\mathrm{RCH} 1, \mathrm{ft} / \mathrm{d}$ & .00274 & .00269 & .00184 & .00243 & .00250 \\
$\mathrm{RCH} 2, \mathrm{ft} / \mathrm{d}$ & .000807 & $\mathrm{NE}$ & $\mathrm{NE}$ & .000774 & $\mathrm{NE}$ \\
$\begin{array}{l}\text { Sum- } \mathrm{of}- \\
\text { squares } \\
\text { error }\end{array}$ & 513 & 473 & 762 & 509 & 467 \\
\hline
\end{tabular}

Table 4. Water budget computed by alternative models, Calvert City, Kentucky

[CAL, calibration; NE, not estimated; in millions of cubic feet per day]

\begin{tabular}{lccccc}
\hline \multicolumn{1}{c}{ Source or sink } & CAL0 & CAL1 & CAL2 & CAL3 & CAL4 \\
\hline \multirow{2}{*}{ Inflow } & & & \\
Flow from Kentucky Lake & $\mathrm{NE}$ & $\mathrm{NE}$ & 0.41 & $\mathrm{NE}$ & $\mathrm{NE}$ \\
Net recharge & 2.79 & 2.46 & 1.45 & 2.45 & 2.31 \\
Total in & 2.79 & 2.46 & 1.86 & 2.45 & 2.31 \\
& \multicolumn{2}{c}{ Outflow } & & & \\
Wells & .48 & .48 & .48 & .48 & .48 \\
Cypress Creek & .048 & .052 & .027 & .052 & .052 \\
Tennessee River & 2.26 & 1.93 & 1.36 & 1.93 & 1.77 \\
Total out & 2.79 & 2.46 & 1.87 & 2.46 & 2.30 \\
\hline
\end{tabular}

\section{Reliability of Estimates}

Parameter estimates obtained through nonlinear regression are likely to be reliable if the estimates are precise and uncorrelated, the residuals are random and normally distributed, and the model is correct. Statistical techniques used to analyze linear regression can he used for nonlinear regression if the model is linear near the estimated parameter values. In particular, confidence intervals can be computed from the standard deviation of the estimates, and are a convenient means of graphically displaying the precision of the estimates. The modified Beale's measure presented by Cooley and Naff (1990) and adapted for use 
with MODFLOWP by Hill (1994) was used to determine whether this criterion was met. The critical value of Beale's measure was computed using the $F$ distribution for 57 observations, 6 parameters, and a 95-percent confidence interval. Beale's measure, 2.71, computed from the calibrated model (CAL1) is greater than the critical value of 0.45 ; therefore, the calibrated model is highly nonlinear near the estimated parameter values and confidence intervals were not calculated.Because confidence intervals were not calculated, the precision of the estimates was assessed by using pseudo-coefficients of variation (M.C. Hill, U.S. Geological Survey, written commun., 1994). Pseudo-coefficients of variation were needed because log-transformed values were estimated, and their coefficients of variation were not directly comparable. Pseudo-coefficients of variation were computed as follows:

$$
X=\frac{e^{b}-e^{a}}{4 e^{p}}
$$

where

$X$ is the pseudo-coefficient of variation (dimensionless);

$e \quad$ is the base for natural logarithms (dimensionless);

$b$ is the upper 95-percent linear confidence-interval boundary calculated for the log-transformed parameter $(\mathrm{ft})$;

$a$ is the lower 95-percent linear confidence-interval boundary calculated for the log-transformed parameter (ft); and

$p \quad$ is the parameter estimate ( $\mathrm{ft})$.

In comparing parameter estimates, a smaller pseudo-coefficient of variation indicated a more precisely estimated parameter. Estimates of parameters to which the model was insensitive had high pseudocoefficients of variation. The pseudo-coefficients of variation of the calibrated model ranged from 0.17 to 13.1 (table 5). All parameters were estimated with approximate equal reliability except the transmissivity of faults and GHB in CAL2. The precision of the estimates could be reduced by collection of additional data from areas in which the model is sensitive to the parameter. For example, model sensitivity to hydraulic conductivity in an area where there is a steep hydraulic gradient and few head measurements could be improved by additional head measurements.

Recharge to the McNairy Formation and the transmissivity of the alluvium were correlated at $r=0.91$ in the calibrated model (table 6). Correlation between recharge and transmissivity was expected because the ground-water-flow equation can be written in terms of their ratio (Hill, 1992). Unless independent information on recharge or transmissivity is available, the regression cannot be used to distinguish each individual component of the ratio.

The effects of correlated parameters of the calibrated model were investigated by holding the transmissivity of the alluvium constant at minimum and maximum reasonable values, 5,000 and $50,000 \mathrm{ft}^{2} / \mathrm{d}$, respectively, and the other parameters were estimated. Estimates of recharge (RCH1) were $0.00119 \mathrm{ft} / \mathrm{d}(5 \mathrm{in} . / \mathrm{yr})$ and $0.00559 \mathrm{ft} / \mathrm{d}(24.5 \mathrm{in} . / \mathrm{yr})$ for the two models, respectively, and were consistent with the correlation between recharge and transmissivity. All but one of the other estimated parameter values differed slightly from the parameter values in table 3 because the correlation was not perfect $(r=1.00)$. One estimated parameter, KRB in the first simulation, differed greatly from the parameter values in table 3 (by a factor of 21,000 ). This increase was possibly caused by nonlinearity in the model. 
Table 5. Pseudo-coefficients of variation for alternative models computed by nonlinear regression, Calvert City, Kentucky

[CAL, calibration; NE, not estimated; CAL1 is calibrated model]

\begin{tabular}{lcccrr}
\hline \multicolumn{1}{c}{ Parameter } & CALO & \multicolumn{1}{c}{ CAL1 } & \multicolumn{1}{c}{ CAL2 } & CAL3 & \multicolumn{1}{c}{ CAL4 } \\
\hline $\mathrm{T} 1$ & 0.23 & 0.23 & 0.39 & 0.24 & 0.24 \\
$\mathrm{~T} 2$ & .26 & .21 & .23 & .33 & .28 \\
$\mathrm{~T} 3$ & $\mathrm{NE}$ & $\mathrm{NE}$ & $\mathrm{NE}$ & 2.01 & 4.53 \\
$\mathrm{GHB}$ & $\mathrm{NE}$ & .37 & 13.1 & $\mathrm{NE}$ & .43 \\
$\mathrm{KDR}$ & .25 & .31 & .24 & .24 & .31 \\
$\mathrm{KRB}$ & .40 & .39 & .48 & .49 & .49 \\
$\mathrm{RCH} 1$ & .30 & .17 & .23 & .31 & .20 \\
$\mathrm{RCH} 2$ & .63 & $\mathrm{NE}$ & $\mathrm{NE}$ & .65 & $\mathrm{NE}$ \\
Sum-of-squares & 513 & 472 & 763 & 509 & 467 \\
error & & & & & \\
\hline
\end{tabular}

Table 6. Correlation and covariance matrix for optimum values obtained through nonlinear regression (CAL1), Calvert City, Kentucky

[Shaded portion is scaled variance/covariance matrix; unshaded portion is the correlation matrix]

\begin{tabular}{ccccccc}
\hline Parameter & KRB & RCH1 & T1 & KDR & T2 & GHB \\
\hline KRB & 0.1279 & $7.507 \times 10^{-5}$ & $1.886 \times 10^{-2}$ & $7.534 \times 10^{-2}$ & $2.288 \times 10^{-2}$ & $8.109 \times 10^{-2}$ \\
RCH1 & .45 & $2.157 \times 10^{-7}$ & $5.600 \times 10^{-5}$ & $2.164 \times 10^{-5}$ & $9.152 \times 10^{-5}$ & $-4.732 \times 10^{-5}$ \\
T1 & .24 & .55 & $4.7950 \times 10^{-2}$ & $-1.037 \times 10^{-2}$ & $1.229 \times 10^{-2}$ & $-2.427 \times 10^{-2}$ \\
KDR & .71 & .16 & -.16 & $8.782 \times 10^{-2}$ & $1.477 \times 10^{-2}$ & $6.99 \times 10^{-2}$ \\
T2 & .30 & .91 & .26 & .23 & $4.678 \times 10^{-2}$ & $-2.178 \times 10^{-2}$ \\
GHB & .67 & -.30 & -.33 & .70 & -.30 & .1151 \\
\hline
\end{tabular}

\section{Simulated Ground-Water Flow}

A particle-tracking technique was used to illustrate the simulated ground-water flow system. First, the volumetric flow rates generated by MODFLOW were used to define a continuous velocity field within each model cell by computing the average linear velocity vectors. Particles, which represent a tiny volume of ground water, then were selectively placed in model cells and allowed to move within the velocity field. The location and cumulative time of travel were recorded for each particle; these characteristics were used to depict the contributing areas to discharge boundaries and the time required for a particle to reach a discharge boundary. Knowledge of the direction and rate of flow beneath waste-disposal units within the 
industrial complex could be used in the management and abatement of the ground-water resource; therefore, the average linear velocity was computed and tabulated at selected locations in the industrial complex. The average linear velocity is defined as

$$
\hat{\imath}=\frac{Q}{A n}
$$

where

$\hat{v} \quad$ is the average linear velocity $(\mathrm{ft} / \mathrm{d})$;

$Q$ is the volumetric flow, $\left(\mathrm{ft}^{3} / \mathrm{d}\right)$;

$A$ is the area of flow $\left(\mathrm{ft}^{2}\right)$; and

$n$ is the porosity of the aquifer, dimensionless.

The location of particles at the start of the simulation must be specified by the investigator. In this study, one particle was placed at the center of the top face of all cells. As each particle moved to a discharge boundary, the beginning and ending coordinates were recorded. The beginning locations of particles were grouped by discharge boundary to produce maps showing the contributing areas (fig. 22).

In this study, it was specified by the investigator that particles would not discharge to weak sinks. Model cells representing the Tennessee River and wells at company A and the Calvert City Water Company were strong sinks because all water that flowed into the model cell discharged through the boundary. In a model cell that is a weak sink, some water discharges through the boundary, but some water flows into an adjacent model cell. For example, Cypress Creek does not extend to the base of the aquifer, so water near the top of the aquifer can discharge to the creek and water at the base of the aquifer can flow beneath the creek to the other side. The weak-sink effect also was evident at model cells representing wells of companies B and C (fig. 22). Whether a well is a weak sink or not is solely a function of the model grid design and does not indicate the efficiency of a particular well in regard to capturing ground-water flow.

Eliminating weak sinks from the simulation was reasonable because the primary concern was the contributing area to the public-water supply wells at the Calvert City Water Company. Additional data on the vertical hydraulic gradients would have been necessary to determine the nature of particle discharge to weak sinks. If these data are incomplete and particles were allowed to discharge to weak sinks, some particles that would otherwise have discharged to the water-company wells would have discharged incorrectly to the weak sink and the contributing area to the wells would be too small.

\section{Contributing Areas and Times of Travel}

Contributing areas for the wells at ISP and the Calvert City Water Company (fig. 22) were $1.27 \times 10^{8} \mathrm{ft}^{2}\left(4.54 \mathrm{mi}^{2}\right)$ and $7.14 \times 10^{7} \mathrm{ft}^{2}\left(2.56 \mathrm{mi}^{2}\right)$, respectively. The two areas are contiguous and extend from the wells to the southem boundary of the model. Model results indicate that particles discharge to Cypress Creek from a small area along its lower reach but not along its upper reach. Particles did not discharge to the upper reach of Cypress Creek or to wells at B.F. Goodrich and Estron because they are weak sinks. Particles in most of the area discharge to the Tennessee River. 

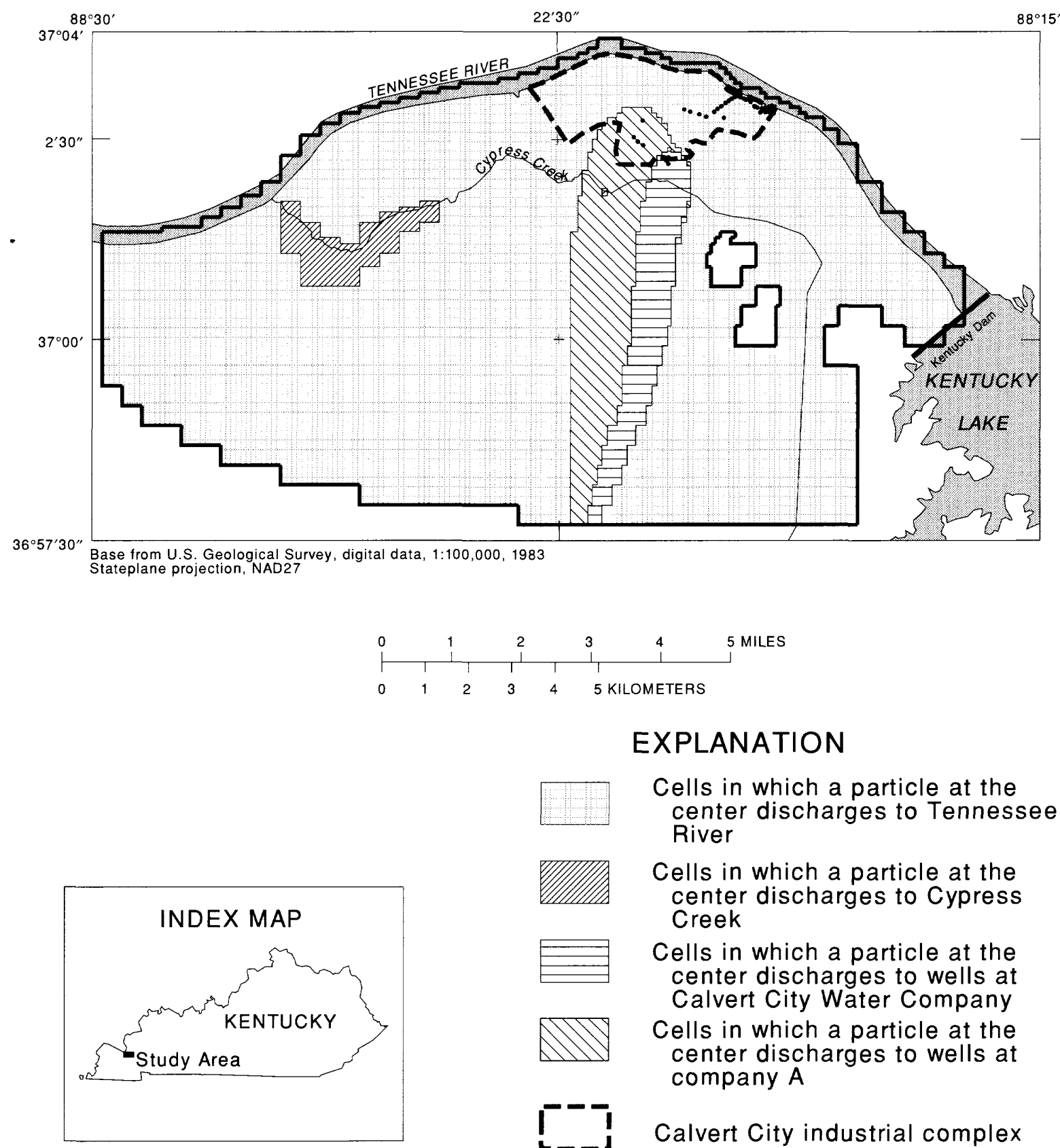

\section{EXPLANATION}

Cells in which a particle at the center discharges to Tennessee River

Cells in which a particle at the center discharges to Cypress Creek

Cells in which a particle at the center discharges to wells at Calvert City Water Company

Cells in which a particle at the center discharges to wells at company A

I- Calvert City industrial complex

Limit of active model

grid; no-flow boundary

Pumped wells

Figure 22. Contributing areas of discharge boundaries computed with the calibrated model, 1992 conditions. 
An additional particle-lracking analysis was performed to simulate the effects of pumping from new wells drilled by the Calvert City Water Company (fig. 23). For this simulation, which approximated 1994 conditions (Jerry Devine, Calvert City Water Company, oral commun., 1994), the number of wells and rates of pumping were kept the same as for the calibrated model and only the locations were changed. Contributing areas to the wells at ISP and the Calvert City Water Company under predicted 1994 conditions were $1.31 \times 10^{8} \mathrm{ft}^{2}\left(4.71 \mathrm{mi}^{2}\right)$ and $9.79 \times 10^{7} \mathrm{ft}^{2}\left(3.51 \mathrm{mi}^{2}\right)$, respectively. The main effect of the new wells was to split the contributing areas between wells at the Calvert City Water Company and ISP. This separation reduced the hydraulic gradient—and thus reduced the rate of flow — causing the contributing areas to increase relative to the calibrated model. The contributing area to the wells at the Calvert City Water Company also increased because the hedrock outcrop south of the new location caused particles from a large area to be channeled toward the wells.

The contributing area to wells at the Calvert City Water Company in the calibrated model did not include the Calvert City Industrial Complex, under simulated conditions. The contributing area to wells at the Calvert City Water Company under predicted 1994 conditions was farther removed from the industrial complex than for the calibrated model.

The time required for a particle to move through the aquifer from its point of recharge to its point of discharge depends on where the particle enters the aquifer. The cumulative times of travel, computed by MODPATH, range from a few days to more than 100 years. Bands of equal time of travel are parallel to surface-water discharge boundaries and are approximately concentric about well discharge boundaries (fig. 24). The time of travel increases with distance from the discharge boundary. The time required for water to move through the unsaturated zone above the aquifer is not included in these estimates.

\section{Average Linear Ground-Water Velocities}

The average linear velocity was computed at the center of model cells spaced evenly throughout the industrial complex area (fig. 25 and table 7). MODPATH computes the orthogonal components of the average linear velocities in the $\mathrm{x}$ and $\mathrm{y}$ directions. The rate of horizontal flow in the aquifer is

$$
V=\sqrt{V_{x}^{2}+V_{y}^{2}},
$$

where

$V \quad$ is the rate of horizontal flow in the aquifer $\left(\mathrm{LT}^{-1}\right)$,

$V_{x}$ is the average linear velocity in the $\mathrm{x}$ direction $\left(\mathrm{LT}^{-1}\right)$, and

$V_{y} \quad$ is the average linear velocity in the y direction $\left(\mathrm{LT}^{-1}\right)$. 

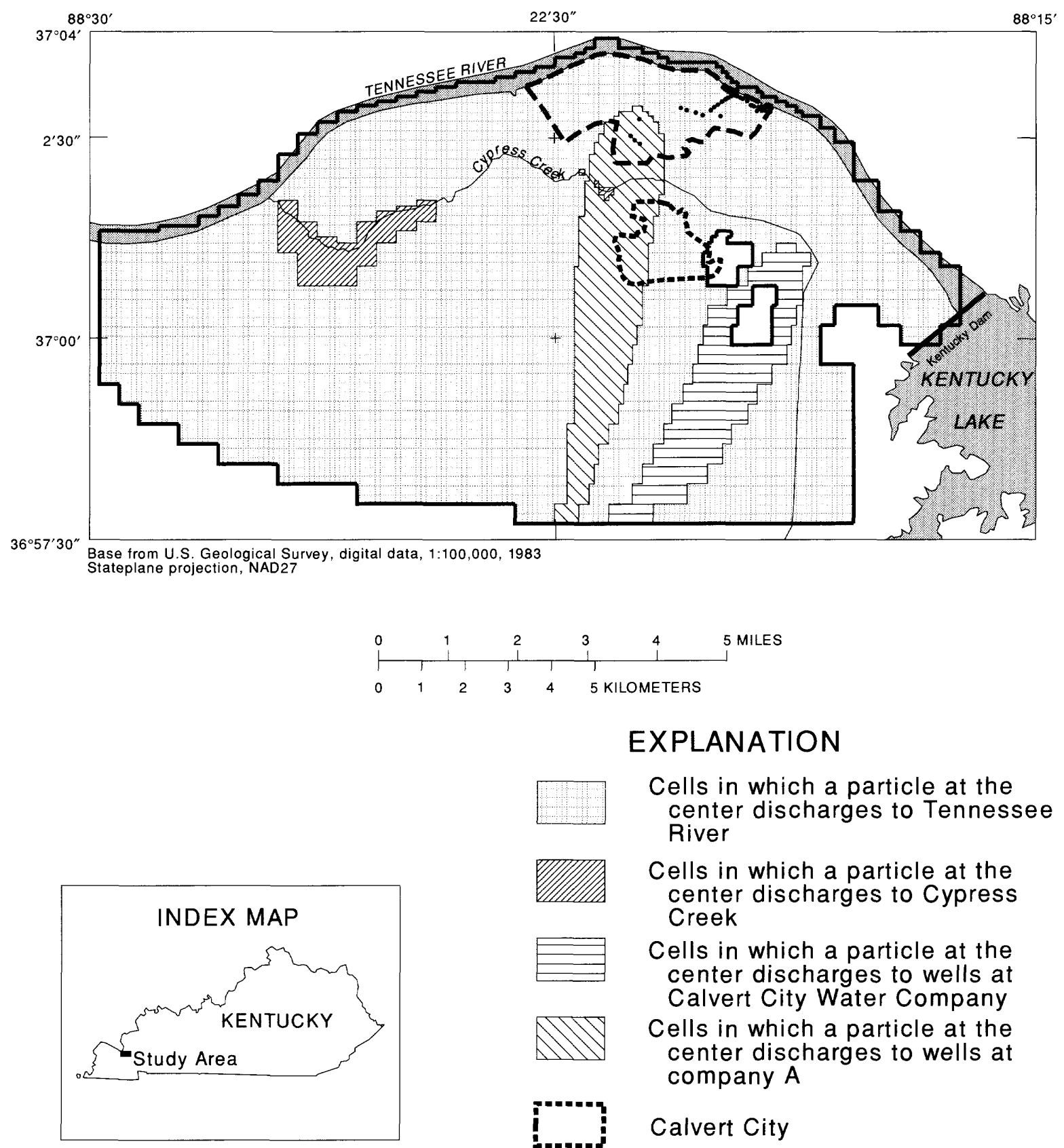

\section{EXPLANATION}

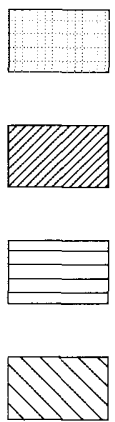

Cells in which a particle at the center discharges to Tennessee River

Cells in which a particle at the center discharges to Cypress Creek

Cells in which a particle at the center discharges to wells at Calvert City Water Company

Cells in which a particle at the center discharges to wells at company $\mathrm{A}$

Calvert City

- Calvert City industrial complex

- Limit of active model

grid; no-flow boundary

Pumped wells

Figure 23. Contributing areas of discharge boundaries computed with the calibrated model, 1994 conditions. 


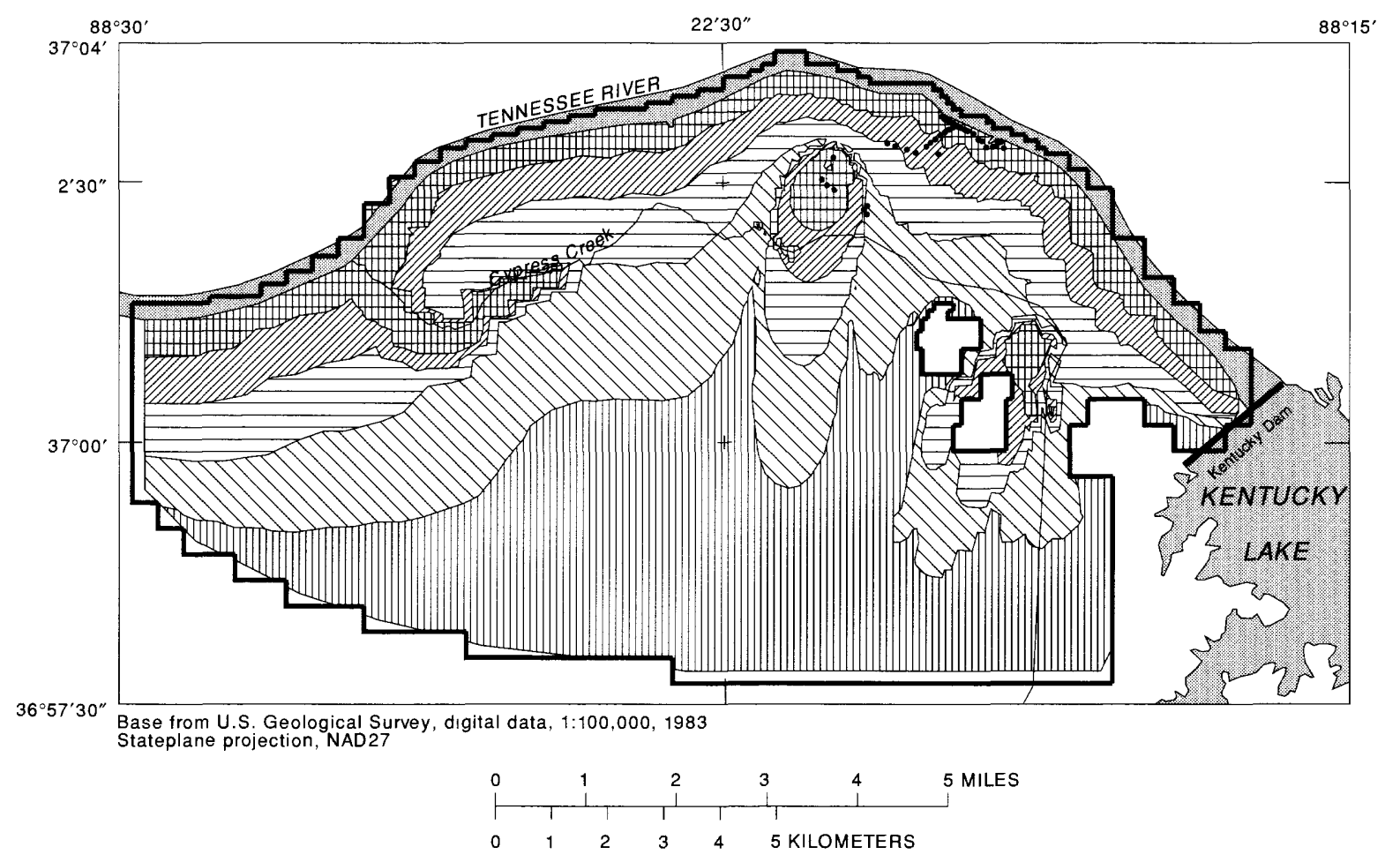

\section{EXPLANATION \\ ZONE OF EQUAL TIME OF TRAVEL}
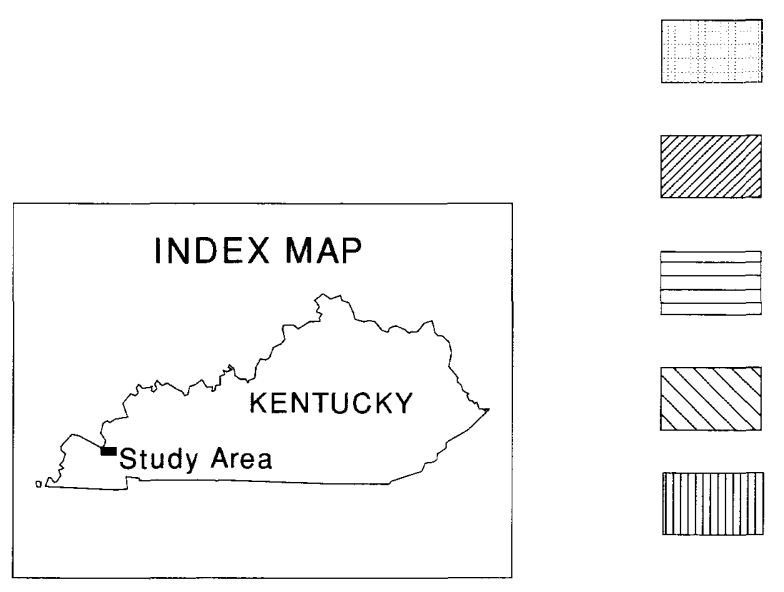

Zone with particle time of travel 0-2 years to discharge area.

Zone with particle time of travel 2-5 years to discharge area.

Zone with particle time of travel 5-10 years to discharge area.

Zone with particle time of travel 10-20 years to discharge area.

Zone with particle time of travel greater than 20 years to discharge area. Maximum is 123 years.

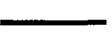

Limit of active model grid; no-flow boundary

LINE OF EQUAL TIME OF TRAVEL-Based on velocities calculated by calibrated model. Contour interval variable

Pumped wells

Figure 24. Time of travel computed with the calibrated model, 1994 conditions. 

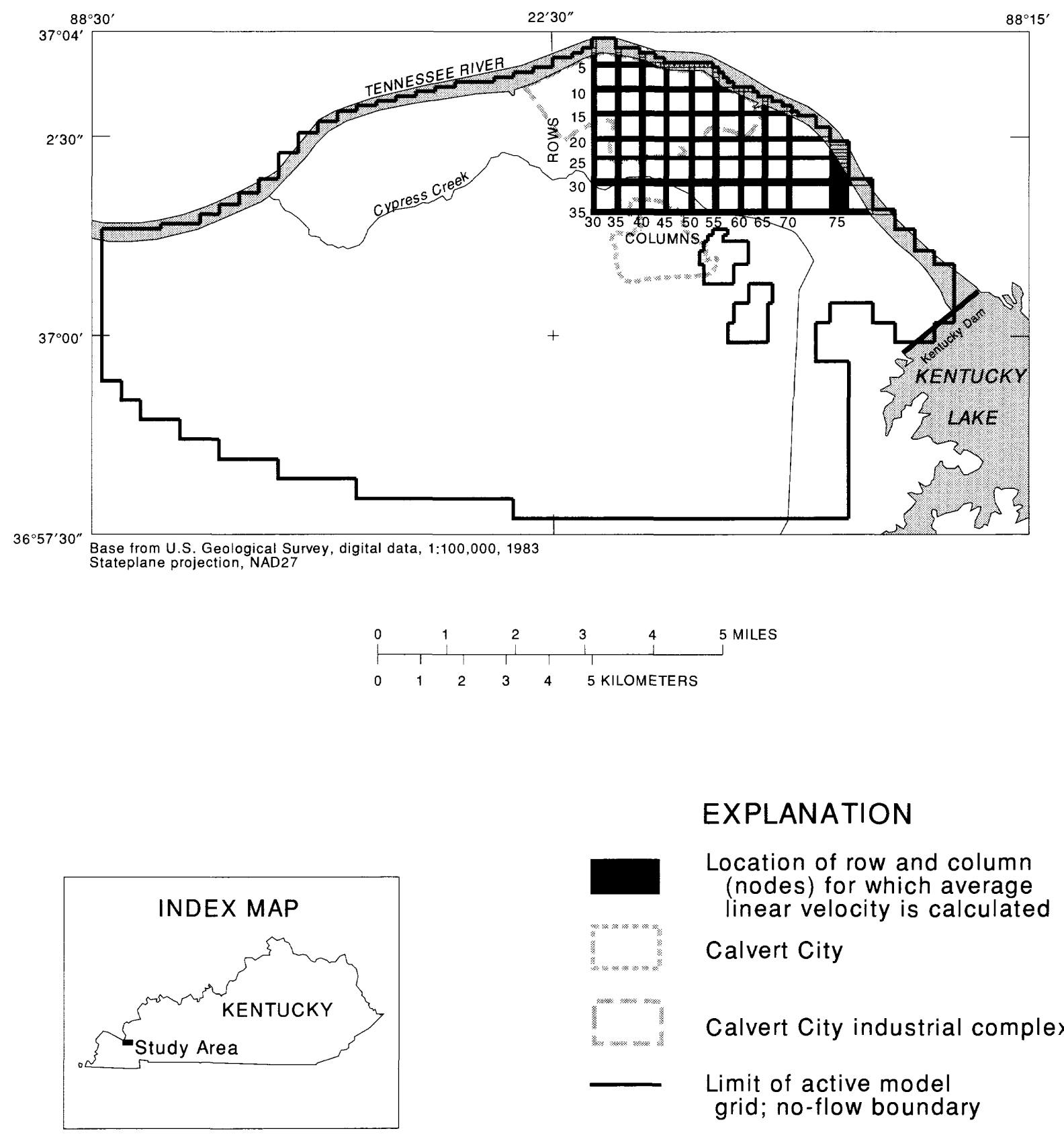

\section{EXPLANATION}

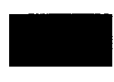

Location of row and column (nodes) for which average linear velocity is calculated Calvert City Calvert City industrial complex Limit of active model grid; no-flow boundary

Figure 25. Location of nodes for which average linear velocity is calculated, 1994 conditions. 
Table 7. Magnitude and direction of the average linear velocity at selected model cells under 1994 conditions, Calvert City, Kentucky

[ALV, average linear velocity; $\mathrm{ft} / \mathrm{d}$, feet per day; 0 degrees or 360 degrees refers to north on the State Plane projection, South Zone, North American Datum, 1987]

\begin{tabular}{|c|c|c|c|c|c|c|c|}
\hline Row & Column & $\begin{array}{l}\text { ALV } \\
\text { (ft/d) }\end{array}$ & $\begin{array}{c}\text { Azlmuth } \\
\text { (degrees) }\end{array}$ & Row & Column & $\begin{array}{c}\text { ALV } \\
\text { (ft/d) }\end{array}$ & $\begin{array}{c}\text { AzImuth } \\
\text { (degrees) }\end{array}$ \\
\hline 5 & 30 & 1.94 & 177.1 & 15 & 50 & 2.02 & 22.4 \\
\hline 10 & 30 & 1.50 & 4.2 & 20 & 50 & 1.98 & 13.2 \\
\hline 15 & 30 & 1.53 & 20.7 & 25 & 50 & 1.83 & 16.4 \\
\hline 20 & 30 & 2.28 & 23.6 & 30 & 50 & 2.06 & 24.4 \\
\hline 25 & 30 & 2.52 & 15.3 & 35 & 50 & 2.77 & 31.8 \\
\hline 30 & 30 & 2.60 & 9.5 & 10 & 55 & 2.96 & 56.5 \\
\hline 35 & 30 & 2.64 & 7.6 & 15 & 55 & 2.62 & 22.0 \\
\hline 5 & 35 & 2.02 & 4.9 & 20 & 55 & 2.05 & 20.0 \\
\hline 10 & 35 & 1.21 & 15.6 & 25 & 55 & 1.74 & 25.6 \\
\hline 15 & 35 & 1.17 & 62.9 & 30 & 55 & 1.79 & 36.4 \\
\hline 20 & 35 & 4.47 & 44.0 & 35 & 55 & 2.37 & 56.6 \\
\hline 25 & 35 & 3.24 & 13.7 & 15 & 60 & 2.92 & 12.2 \\
\hline 30 & 35 & 2.74 & 9.5 & 20 & 60 & 2.15 & 20.7 \\
\hline 35 & 35 & 2.70 & 7.9 & 25 & 60 & 1.69 & 30.4 \\
\hline 5 & 40 & 1.95 & 13.8 & 30 & 60 & 1.49 & 44.8 \\
\hline 10 & 40 & 1.08 & 11.7 & 35 & 60 & 1.43 & 66.5 \\
\hline 15 & 40 & .90 & 105.0 & 15 & 65 & 2.69 & 6.1 \\
\hline 20 & 40 & 3.21 & 145.7 & 20 & 65 & 1.83 & 24.9 \\
\hline 25 & 40 & 2.91 & 176.5 & 25 & 65 & 1.54 & 38.2 \\
\hline 30 & 40 & 2.65 & 8.0 & 30 & 65 & 1.51 & 49.6 \\
\hline 35 & 40 & 2.76 & 10.4 & 35 & 65 & 1.28 & 61.0 \\
\hline 10 & 45 & 1.44 & 15.9 & 20 & 70 & 1.65 & 41.8 \\
\hline 15 & 45 & 1.51 & 1.4 & 25 & 70 & 1.71 & 50.0 \\
\hline 20 & 45 & 2.03 & 174.7 & 30 & 70 & 1.67 & 57.3 \\
\hline 25 & 45 & 2.10 & 2.4 & 35 & 70 & 1.42 & 62.4 \\
\hline 30 & 45 & 2.34 & 13.0 & 30 & 75 & 1.76 & 62.0 \\
\hline 35 & 45 & 2.73 & 18.6 & 35 & 75 & 1.83 & 60.4 \\
\hline 10 & 50 & 1.94 & 31.7 & & & & \\
\hline
\end{tabular}


The direction of flow with respect to the positive $\mathrm{x}$ axis is

$$
\theta=\operatorname{atan}\left(\frac{V^{y}}{V_{x}}\right),
$$

where

$\theta$ is the direction of flow with respect to the positive $\mathrm{x}$ axis, in degrees, and

$\operatorname{atan} x$ is the arctangent of argument $\mathrm{x}$.

The azimuth is obtained by adding $90^{\circ}$ to $\theta$. The model grid was oriented parallel to the axes of the State Plane Projection, South Zone, North American Datum, 1987. The azimuth is reported with respect to north in this projection. The average linear velocities ranged from 0.90 to $4.47 \mathrm{ft} / \mathrm{d}$.

\section{Limitations of Particle Tracking}

Particle tracking is subject to uncertainty that stems from variance in the parameters of the model. The particle tracking presented here was deterministic; that is, one set of parameters was used resulting in one outcome of the particle tracking. Although the optimal parameter values (the ones that minimize the SSE) were used in the model, uncertainty in the parameters is translated into uncertainty in the size and shape of the contributing area. Some statistical measures can be derived from the regression that indicate the uncertainty of the computed parameters and thus of the contributing area. The variance-covariance matrix is a "measure of the range over which the respective parameter may be varied to produce a similar solution for the dependent variable as that obtained using ... [the optimal parameter set. The variance-covariance matrix also] . . . gives an estimate of the degree of linear dependence of one parameter on another throughout the course of repeated experiments if such experiments were to be carried out" (Cooley and Naff, 1990). This type of analysis is beyond the scope of this report.

An additional parameter not represented in the variance-covariance matrix, porosity, was required to compute the average linear velocity. Porosity was estimated at 20 percent based on geologic description of the lower alluvial unit and sand layers in the McNairy Formation. The actual value of porosity is not a source of uncertainty, it is simply a constant factor in the calculation of average linear velocity. The uncertainty stems from the assumption that one value characterizes the average porosity in both the alluvium and the McNairy Formation. Based on the geologic description of each aquifer — one is sand and gravel and the other is sand-the porosities are probably similar. Because of the interbedded character of the McNairy Formation, true flow paths would be more complex in the vertical direction than was simulated in the calibrated model.

The resolution of contributing areas was limited by the number of particles used. Using more particles would more closely approximate the true boundaries that lie between the center of cells on either side of the boundary of the contributing areas (figs. 22 and 23). A method that would produce higher resolution of the contributing areas would be to place particles in each cell of the model grid that is a discharge point. The particles would be assigned to sides of the grid cell in proportion to the amount of flow through that side, as determined by MODFLOW. In this method, the path of the particle would be tracked backwards to the point of recharge to delineate the contributing area. The resolution of the contributing areas in the calibrated model was deemed sufficient for the purposes of this study and represents a compromise between higher resolution and increased computer time. 
The movement of particles differs from the movement of a conservative solute in ground water, such as a contaminant. A discrete mass of solute (for example, a contaminant plume) can be represented by a group of particles, the distribution of which will be affected by variation in the velocity of ground-water flow. This variation causes solute dispersion on a wide range of scales: from within individual pores in the aquifer, within geologic units, and between geologic units. The net effect of dispersion is that the solute mixes with uncontaminated ground water and hecomes diluted. Apparent dispersion of a solute also can occur through temporal changes in the velocity of ground-water flow at boundaries, such as changes in river stage. Change in river stage causes more spreading and dilution of the solute as it moves closer to the river (Starn, in press). Particle tracking by itself does not account for dispersion. The average linear velocity is the rate at which the center of mass of the group of particles moves, provided there are no biological, physical, or chemical processes that alter the concentrations of the solute. 


\section{SUMMARY AND CONCLUSIONS}

The aquifer at Calvert City, Ky., consists of atluvial sediments of Quaternary age, unconsolidated sediments of the McNairy Formation of Cretaceous age, and weathered limestone bedrock of Mississippian age. The altuvial sediments are composed of three units: the lower gravel and sand unit, the middle interbedded sand and clay unit, and the upper clayey lacustrine deposits. The McNairy Formation is composed mostly of unconsolidated sand interbedded with silty clay. The alluvium and the McNairy Formation are underlain by fractured and weathered bedrock. Several faults displace strata of the McNairy Formation and the bedrock.

Recharge to ground water is from the uplands south of Calvert City underlain by the McNairy Formation. Ground water discharges to the Tennessee River, to the upper and lower reaches of Cypress Creek, and to pumped wells. The saturated thickness of the alluvium is 80 to $100 \mathrm{ft}$, which includes the middle unit that forms a leaky confining layer over the aquifer. Transmissivity of the alluvium determined from aquifer tests ranges from 2,940 to $174,000 \mathrm{ft}^{2} / \mathrm{d}$ (Davis and others, 1973). The maximum value may reflect the presence of localized transmissive faults in the bedrock.

Ground-water flow in the aquifer was simulated in a two-dimensional, steady-state model. The hydraulic properties and boundary conditions of the aquifer were represented by parameters in a nonlinear regression. The parameters of the regression were the transmissivity of the alluvium, the transmissivity of the McNairy Formation, conductance of a general-head boundary representing recharge to the alluvium, specified flow representing recharge to the McNairy Formation, conductance of the bed of Cypress Creek, and leakance of the bed of the Tennessee River. The regression procedure calibrated the model to 55 measurements of head in the aquifer and 2 measurements of streamflow in Cypress Creek. The optimal parameters of the model were computed such that the sum of the weighted difference between observed and calculated heads and flows was minimized. Weights used in the regression account for error in the measurements of heads and flows and for the difference in units between heads and flows ( $\mathrm{ft}_{\text {and }} \mathrm{ft}^{3} / \mathrm{d}$ ).

Transmissivity of the alluvium and the McNairy Formation were estimated to be approximately equal $\left(20,000\right.$ and $\left.19,000 \mathrm{ft}^{2} / \mathrm{d}\right)$. The rate of recharge to the McNairy Formation was estimated to be $0.00269 \mathrm{ft} / \mathrm{d}$ (11.8 in./yr). Although the rate of recharge to the alluvium was estimated using a head-dependent flow boundary, the average rate of recharge was $0.000484 \mathrm{ft} / \mathrm{d}(2.1 \mathrm{in} . / \mathrm{yr})$. Higher estimated recharge to the McNairy Formation than to the alluvium supported the conceptual model that the upper alluvial unit limits recharge to the alluvium.

The calculated pattern of hydraulic head conformed to the expected pattern. The weighted residuals (difference between observed and predicted values) ranged from -9.92 to $8.4 \mathrm{ft}$. Only 5 values (out of the total of 55) were less than $-5 \mathrm{ft}$ or greater than $5 \mathrm{ft}$ and 71 percent of all weighted residuals were between -3 and $3 \mathrm{ft}$. The weighted residuals of the calibrated model were distributed randomly over the modeled area except in the northwestern part, where simulated heads were consistently greater than observed heads. This may have been the result of unknown variations in aquifer properties.

Alternative models were tested to determine if some model other than the calibrated model provided a better fit to the observed data or provided more reliable parameter estimates. In general, the parameter estimates were similar for the calibrated model and the alternative models. The weighted residuals also were similar for the calibrated and alternative models; therefore, bias in the calibrated model was not corrected through different boundary conditions in the alternative models. Models that simulate headdependent recharge to the alluvium were better models than those that simulated specified recharge on the basis of lower sum-of-squares error. Models that simulated transmissive faults resulted in slight improvements in model fit; however, estimates of fault transmissivity had a large variance and were considered unreliable. 
Within the limits discussed in the report, the parameters of the calibrated model were reliably estimated. The regression model was found to be nonlinear through application of Beale's measure; thus, no confidence intervals were computed for the model. Recharge to the McNairy Formation and the transmissivity of the alluvium were correlated at $r=0.91$. This is expected because these two parameters are the primary control on inflow to and outflow from the model. To determine the effect of the correlation, transmissivity was fixed at $5,000 \mathrm{ft}^{2} / \mathrm{d}$, which produced a recharge estimate of $0.00119 \mathrm{ft} / \mathrm{d}(5 \mathrm{in} . / \mathrm{yr})$ and at $50,000 \mathrm{ft}^{2} / \mathrm{d}$, which produced a recharge estimate of $0.00559 \mathrm{ft} / \mathrm{d}(24.5 \mathrm{in} . / \mathrm{yr})$.

The contributing areas to discharge boundaries were computed using a particle-tracking technique. The contributing area to wells at the Calvert City Water Company did not include the Calvert City Industrial Complex, under simulated conditions. The contributing area to the wells at the Calvert City Water Company changed when pumping was shifted to a new location. The new contributing area. although larger than that simulated with the calibrated model, was farther from the industrial complex. The time of travel of particles ranged from several days to 123 years depending on the distance from the discharge point. The average linear velocity of ground water ranged from 0.90 to $4.47 \mathrm{ft} / \mathrm{d}$ with a median of $1.98 \mathrm{ft} / \mathrm{d}$. The average linear velocity is the rate at which the center of a mass of contaminated ground water will move; thus, some contaminated water will move more slowly and some will move more rapidly. The alternative models in which transmissive faults were simulated was not used to compute contributing areas; however, new wells at the Calvert City Water Company are near a potentially transmissive fault that may affect the contributing area.

Reliability of estimates from the calibrated model could be increased through additional data collection. Head measurements in the middle alluvial unit would increase the reliability of recharge estimates. Aquifer tests at more locations that include head measurements in the middle and upper alluvial units would provide independent information on aquifer properties and more information on possible spatial changes in aquifer properties. Aquifer tests and (or) head measurements in or near faults would allow more reliable simulation of the effect of transmissive faults on contributing areas. Recharge to the McNairy Formation is complex; more detailed mapping of clay beds and investigation of the unsaturated flow in loess and continental deposits would allow more accurate estimates of the rate and distribution of recharge. Vertical-head data, especially near discharge boundaries and in the McNairy Formation, would allow better representation of particle flow paths.

The results of this study could be used in future studies to answer more detailed questions about ground-water flow in the area. The cell-by-cell flow rates computed by MODFLOW could be used in a model with a smaller grid cell size to eliminate the weak-sink problem and to provide higher resolution contributing areas. Models of smaller areas could used in simulations of solute transport to determine the effect of dispersion on contaminant concentrations. Also, statistical measures computed by the regression could be used to assess the effect of uncertainty in the parameter estimates on contributing areas. 


\section{REFERENCES CITED}

Amos, D.H., and Finch, W.I., 1968, Geology of the Calvert City quadrangle, Livingston and Marshall Counties, Kentucky: U.S. Geological Survey Geologic Quadrangle Map GQ-731, scale 1:24,000.

Amos, D.H., and Wolfe, E.W., 1966, Geology of the Little Cypress quadrangle, Kentucky-Illinois: U.S. Geological Survey Geologic Quadrangle Map GQ-554, scale 1:24,000.

Cooley, R.L., and Naff, R.L., 1990, Regression modeling of ground-water flow: U.S. Geological Survey Techniques of Water-Resources Investigations, book 3, chap. B4, 232 p.

Dames and Moore, 1988a, Report: Remedial investigation, B.F. Goodrich/Airco site, Calvert City, Ky., 85 p., 60 tables, 37 figs., 9 appendices.

1988b, Report: Evaluation of aquifer response during flooding, B.F. Goodrich/Airco site, Calvert City, Ky., 16 p., 3 tables, 16 figs.

1991, Report: Remedial environmental investigation, groundwater assessment, B.F. Goodrich Company, Calvert City, Ky., 67 p., 15 tables, 34 figs., 3 appendices.

Davis, R.W., Lambert, T.W., and Hanson, A.J., Jr., 1973, Subsurface Geology and Ground-Water Resources of the Jackson Purchase Region, Kentucky: U.S. Geological Survey Water-Supply Paper 1987, 66 p., 11 pls., 9 figs.

Fenneman, N.M., 1938, Physiography of the Eastern United States: New York, McGraw-Hill Book Company, 714 p.

Finch, W.I., 1968, Engineering geology of the Calvert City Quadrangle, Livingston and Marshall Counties, Kentucky: Kentucky Geological Survey Information Circular 16, Lexington, Ky., 28 p.

Hill, M.C., 1992, MODFLOWP, A computer program estimating parameters of a transient, three-dimensional groundwater flow model using non-linear regression: U.S. Geological Survey Open-File Report 91-484, 358 p.

1994, Five computer programs for testing weighted residuals and calculating linear confidence intervals on results from the ground-water parameter-estimation computer program MODFLOWP: U.S. Geological Survey Open-File Report 93-481, 81 p.

Lambert, T.W., and MacCary, L.M., 1964, Geology of the Briensburg quadrangle, Kentucky: U.S. Geological Survey Geologic Quadrangle Map GQ-327, scale 1:24,000.

MacCary, L.M., 1964, Availability of ground water in the Briensburg quadrangle, Kentucky: U.S. Geological Survey Hydrologic Atlas HA-114, scale 1:24,000.

McDonald, M.G., and Harbaugh, A.W., 1988, A modular three-dimensional finite-difference ground-water flow model: U.S. Geological Survey Techniques of Water-Resources Investigations, book 6, chap. A1, 528 p.

Morgan, J.H., 1964, Availability of ground water in the Elva quadrangle, Kentucky: U.S. Geological Survey Hydrologic Investigations Allas HA-117, scale 1:24,000.

1965, Availability of Ground-Water in the Parts of the Little Cypress and Calvert City Quadrangles in the Jackson Purchase Region, Kentucky: U.S. Geological Survey Hydrologic Investigations Atlas HA-155, 1 sheet, scale 1:24,000.

Morris, D.A., and Johnson, A.I., 1967, Summary of hydrologic and physical properties of rock and soil materials, as analyzed by the Hydrologic Laboratory of the U.S. Geological Survey, 1948-1960: U.S. Geological Survey Water-Supply Paper 1839-D, 42 p.

Olive, W.W., 1963, Geology of the Elva quadrangle, Kentucky: U.S. Geological Survey Geologic Quadrangle Map GQ-230, scale 1:24,000.

1980, Geologic maps of the Jackson Purchase Region, Kentucky: U.S. Geological Survey Miscellaneous Investigations Map I-1217, scale 1:250,000.

Pollack, D.W., 1989, Documentation of computer programs to compute and display pathlines using results from the U.S. Geological Survey modular three-dimensional finite-difference ground-water flow model: U.S. Geological Survey Open-File Report 89-381, 188 p. 
Pree, H.L.. Jr., and Walker, W.H., 1952, Memorandum on the geology and ground-water resources of the Calvert CityGilbertsville area, Marshall County, Kentucky: U.S. Geological Survey Open-File Report, 13 p.

Sholar. C.J., and Lee, V.D., 1988, Water use in Kentucky, 1985: U.S. Geological Survey Water-Resources Investigations Report 88-4043, 53 p.

Squillace, P.J., Thurman, E.M., and Furlong, E.T., 1993. Groundwater as a nonpoint source of atrazine and deethylatrazine in a river during base flow conditions: Water Resources Research. v. 29. no. 6, p. 1719-1729.

Starn, J.J., in press, Apparent solute dispersion in an alluvial-aquifer/stream system. in Morganwalp, D.W.. and Aronson, D.A., eds., U.S. Geological Survey Toxic Substances Hydrology Program-Proceedings of the Technical Meeting, Colorado Springs, Colorado, September 20-24, 1993: U.S. Geological Survey WaterResources Investigations Report 94-4015.

Yager, R.M., 1993. Estimation of hydraulic conductivity of a riverbed and aquifer system on the Susquehanna River in Broome County, New York: U.S. Geological Survey Water-Supply Paper 2387, 49 p.

in press, Simulated three-dimensional ground-water flow in a fractured dolomite aquifer of the Lockport Group near Niagara Falls, New York: U.S. Geological Survey Open-File Report 94-386, 43 p. 